
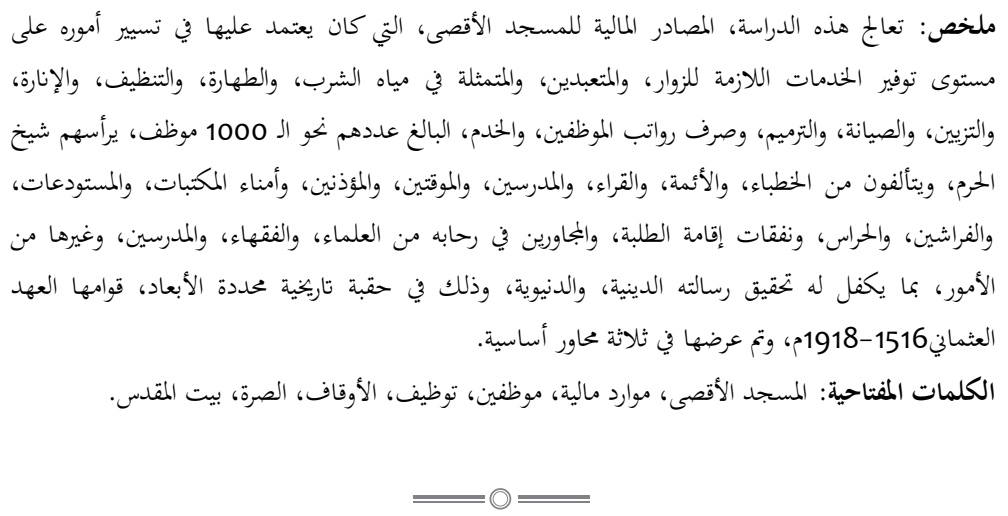

\title{
Financial Sources of Al-Aqsa Mosque 1516-1918
}

ABSTRACT: This study addresses the financial sources of al-Aqsa Mosque, which was dependent on affairs of propulsion at the level of providing the necessary services for visitors and devotees. This is such as providing water for drinking and purification besides cleanliness and lighting, restoration, reconstruction and maintenance. As well and paying the salaries of staff, reaching around 1000 staff, headed by the sheikh of the Haram, consisting of preachers, imams, reciters, teachers, time keepers, muezzins, librarians, janitors, and guards. In addition, it covers bursaries for students, stipends for scholars, jurists, teachers, and other things to ensure it achieves its religious message in a specific historical period, the Ottoman period 1516 -1918 and presenting in in three main themes.

KEYWORDS: al-Aqsa Mosque, finances, staff, employment, Awqaf, Surra, Bayt alMaqdis. 
يعد المسجد الأقصى جزءا من عقيدة المسلمين، وهو ما أكدت عليه نصوص القرآن الكريم، والسنة النبوية، بصفته أولى القبلتين، وثاني المسجدين، وأحد المساجد الثلاث التي لا تشد الرحال إلا إليها،

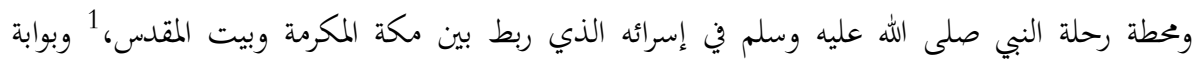
الأرض إلى السماء في رحلة المعراج، ومهبط الوحي، ومصلى الأنبياء ومجمعهم، والأرض المباركة التي بورك فيها، وبمن حولها، لا يعمر فيها ظالم، منها المنشر، وفيها المشر، ثغورها رابطة، وأهلها مرابطه إلى يوم الدين.

وعملا بذلك، غدى مشد رحال المسلمين في مشارق الأرض ومغاربها، ومهوى أفئدةم، ومقصد زياراتم، وغاية أعطياتا، وذلك طمعا في نيل الأجر والثواب، وإزاء ذلك جاوره المتصوفة، والمتعبدون لقضاء بقية العمر في ظلاله، وقصده المدرسون، وأمّه العلماء، والفقهاء، والقضاة، والنحويون، واللغويون، والأدباء، والفلاسفة، لعقد حلقاقم، ومناظراقم في مدارسه، وأروقته، ومساطبه، وارتحل في سبيله الطلبة للنهل من علومه ومعارفه، الأمر الذي جعله منارة علم لها مكانتها بين دور العلم، والتدريس الإسلامية، وأجزل العامة، والخاصة له بالأعطيات، والهدايا، والنذور، وحبسوا عليه الأوقاف المنقولة، وغير المنقولة، وأسهموا بعمارته، وترميمه، وصيانته، عملا بالحديث النبوي الشريف "إذا مات /بن آدم انقطع عمله إلا من ثلاث: صدقة جارية أو علم ينتفع به أو ولد صالح يلعو له" . 2

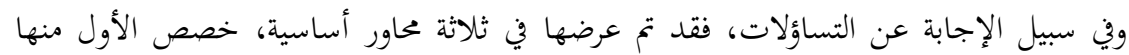
لمعالجة الأوقاف، التي رصدت على مصالحه من العامة، والخاصة، واشتملت على الأموال المنقولة، وغير المنقولة، وتتألف من الأوقاف الصحيحة، وغير الصحيحة، وحازت الأولى على صحتها من خلال ملكية

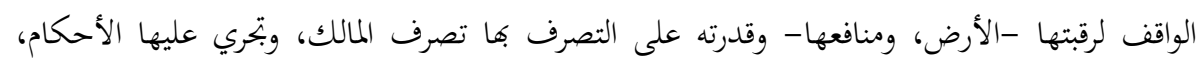
والقواعد الفقهية، وتشمل على العقارات من الأراضي، والمسقفات، المنتشرة داخل العمران وخارجه، شأها في ذلك شأن الأموال المنقولة كالقناديل، والمكتبات، وغيرها. في حين حازت الأخرى على عدم الصحة، لكون وقفها اقتصر على منافع الأرض دون رقبتها، حيث ظلت رقبتها بيد خزينة الدولة، وتتألف من الأراضي الأميرية، القائمة خارج المدن، والقرى، ولا تزال تعرف، في وثائق الملكية المتداولة بين الناس، بالأرصاد، ووقف تخصيصات، وبتري عليها أحكام قوانين الأراضي العثمانية، وسارت على نسقها قوانين الانتداب البريطاني 1920-1948، والحكومة الأردنية 1951-1967. أما الأوقاف المنقولة، فتتألف من المصاحف، والكتب، والمكتبات، والزينات، والمفروشات، والخزائن، والقناديل، والزيت، والشمع اللازم لسرج قناديله، والرسوم، والنقود، والجزية، في حين خصص 
المحور الثاني لعرض دور الصرة، التي كانت ترسل إلى أهالي القدس، وخدمة المسجد من أنحاء العالم الإسلامي، ووفقا للجهات الأربعة، انتظمت بأربع صرر، فمن الشمال الصرة الرومية، والجنوب اليمنية،

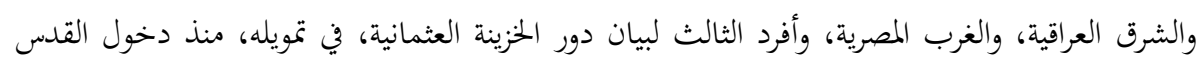
تحت الحكم العثماني؛ وذلك بالاعتماد على المصادر الأولية، وفي مقدمتها سجلات المحاكم الشرعية، ودفاتر الطابو، والأوقاف، وكتب النظم، والقوانين، والتراجم، والفتاوى، وأدب الرحلة، والجغرافيا والخرائط

والجولات الميدانية.

\section{أولا: الأوقاف}

تعد أهمَّم مصادره المالية، نظرا لديمومتها، وضخامة حجمها، وسعة انتشارها، وغزارة إنتاجها، وتنوع منافعها، ومساهمة العامة، والخاصة بحبسها، وتبعا لذلك، قسمت لثلاثة أقسام: الأراضي: أهم أوقافه، وعدت أرصادا لكون رقبتها بيد الخزينة، ويرجع أقدمها للفتح الصلاحي 1187م، وبلغت ذروما بالعهد المملوكي، 3 وعززها السلاطين والولاة، والأعيان، والعلماء، والعامة، بالعهد العثماني 4

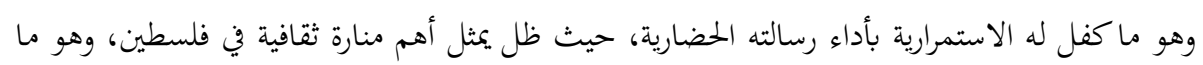
حمل المجلس الإسلامي الأعلى عام 1931م، على تحويله إلى جامعة تعنى بتدريس العلوم الشرعية، تحمل

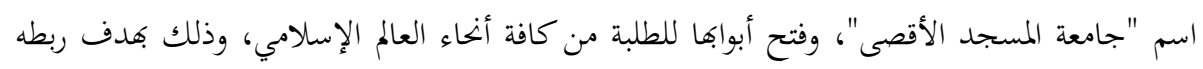

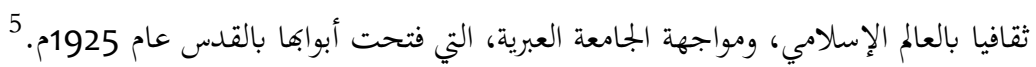
وبموجب الدور الحضاري الذي اطلع به، فقد حبس على مصالحه، مساحات واسعة من الأراضي، والمسقفات انتشرت فيما يفوق الـ 442 موقعا، تحت اسم أوقاف الحرم، أو قبة الصخرة، والأوقاف المندرسة، والملحقة6 أو الحرمين للدلالة على مشاركة الحرم الإبراهيمي له في بعض المواقع، وهو ما تظهره

\begin{tabular}{|c|c|c|c|}
\hline ملاحظات & النسبة & الموقع & الرقم \\
\hline 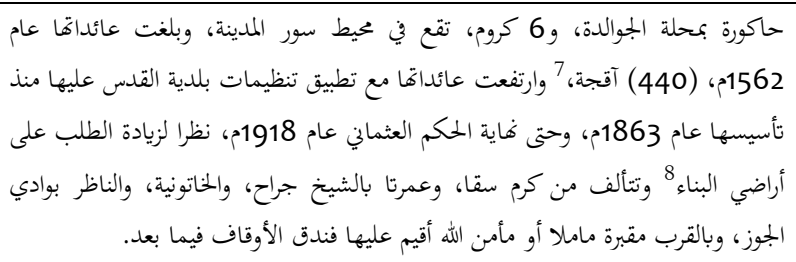 & 100 & مدينة القدس & .1 \\
\hline 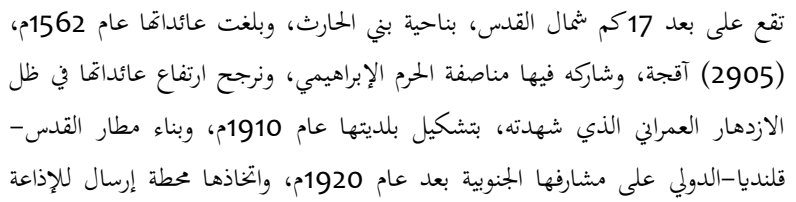 & 100 & قرية رام الله & .2 \\
\hline
\end{tabular}




\begin{tabular}{|c|c|c|c|}
\hline 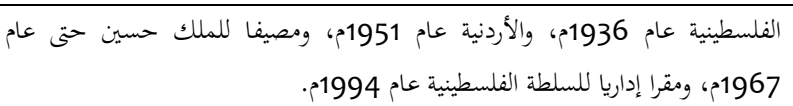 & & & \\
\hline 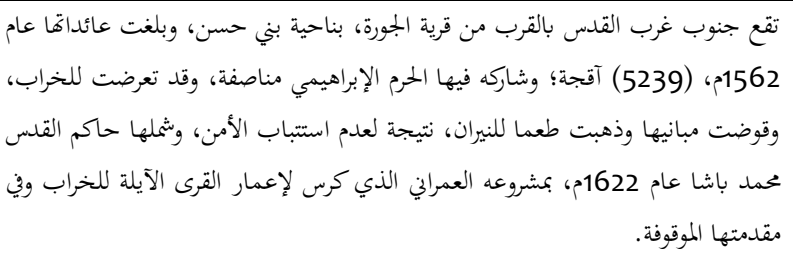 & 58.33 & قرية بيت سقيا & $\cdot 3$ \\
\hline تقع شمال رام الله، بناحية بني الحارث، وقد ارتفعت أثمان أراضيها ارتفاعا لافتا، بإقامة & 100 & 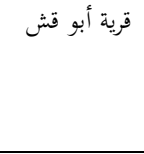 & 4 \\
\hline آقع شمال غرب رام الله، بناحية بني زيد، وبلغت عائداتما عام 1562م، (23480) & 100 & قرية بيت ريما & .5 \\
\hline 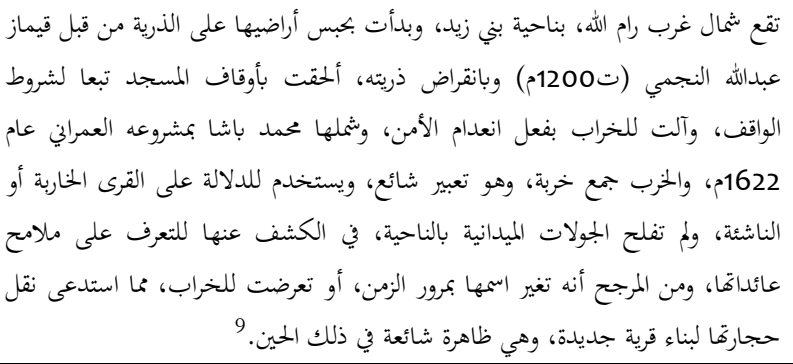 & 100 & 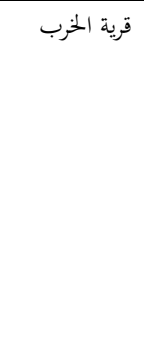 & .6 \\
\hline 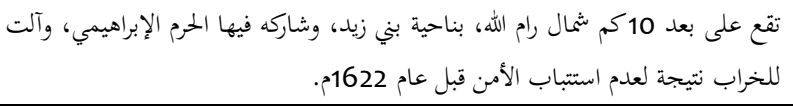 & 100 & قرية جفنا & .7 \\
\hline 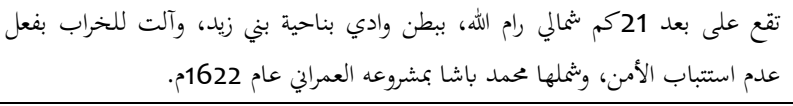 & 100 & قرية عجول & .8 \\
\hline 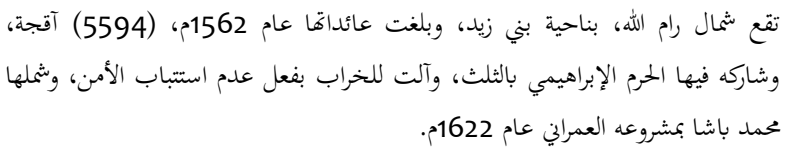 & 100 & قرية عبوين & 9 \\
\hline تقع شمالي رام الله، بناحية بني زيد، وآلت للخراب بفعل عدم استتباب الأمن، وشملها & 100 & قرية عطاره & .10 \\
\hline تآقجع جنوب غرب رام الله، بناحية بني الحارث، وبلغت عائداتما عام 1562م، (18320) & 100 & قرية بيتونيا & .11 \\
\hline شمال غرب رام الله، بناحية بني الحارث، وبلغت عائداتما عام 1562م، (27110) آقجة، & 100 & قرية دجانية & .12 \\
\hline
\end{tabular}




\begin{tabular}{|c|c|c|c|}
\hline وآلت للخراب بفعل عدم استباب الأمن، وشملها محمد باشا بمشروعه العمراني عام & & & \\
\hline تقع شمال غرب رام الله، بناحية بني الحارث، وبلغت عائداتا عام 1622م، آلت للخراب بفعل (5720) & 100 & قرية كفر نعمة & .13 \\
\hline تقع شمال غرب رام الله، بناحية بني زيد، وبلغت عائداها عام1562م، (22560) آقجة. & 100 & 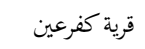 & .14 \\
\hline تقع على بعد 8 كم شمال القدس، بناحية جبل القدس، وبلغت عائداتا عام 1562م، آقجة، وشاركه فيها الحرم الإبراهيمي مناصفة. & 100 & قرية بيت & .15 \\
\hline تقع شمال غرب القدس في ناحية بني مالك، وبلغت عائداتما عام 1562م، (3000) & 100 & قرية بيت عنان & 16 \\
\hline تقع على بعد 7كم للشرق من رام الله، في ناحية بني سليم. & 100 & قرية دير دبوان & .17 \\
\hline تقع بظاهر القدس الجنوبي، بناحية الوادية، وبلغت عائداتا عام 1562م، (3810) & 50 & قرية صور باهر & .18 \\
\hline و وتقع على بعد 12كم شمال شرق القدس، بناحية جبل القدس، وعرفت بطيبة الاسم، & 75 & 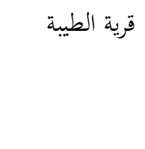 & .19 \\
\hline 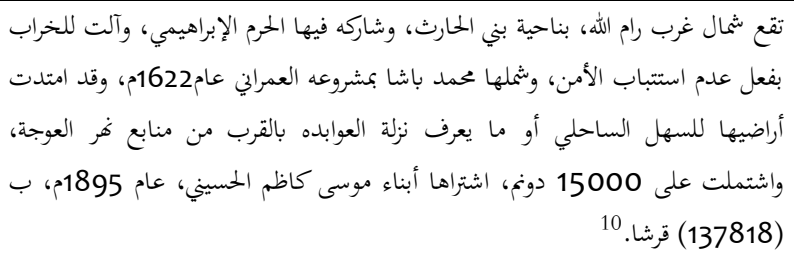 & 100 & قرية عابود & .20 \\
\hline 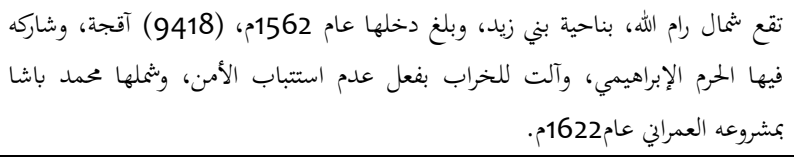 & 100 & ق قرية عارورة & .21 \\
\hline فقتع غربي رام الله، بناحية بني الحارث، وبلغت عائداتا عام 1562م، (3980) آقجة بما & 100 & قرية عين & .22 \\
\hline 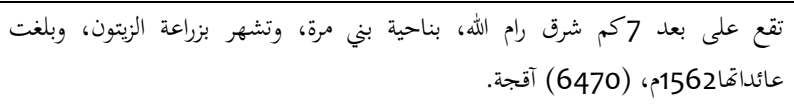 & 67 & قرية عين يبرود & .23 \\
\hline 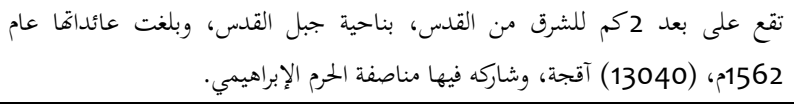 & 100 & 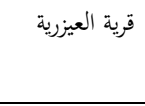 & .24 \\
\hline 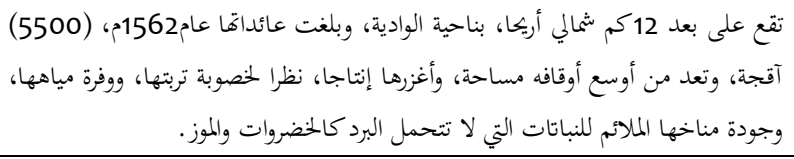 & 100 & قرية العوجة & 25 \\
\hline تقع شمال غرب رام الله، بناحية بني زيد، وبلغت عائداتا عام 1562م، (17933) آقجة، & 92 & قرية قراوة بني & .26 \\
\hline
\end{tabular}




\begin{tabular}{|c|c|c|c|}
\hline وممد باركا بيها مناصفة الحرم الإبراهيمي، وآلت للخراب بفعل عدم استتباب الأمن، وشملها & & زيد & \\
\hline 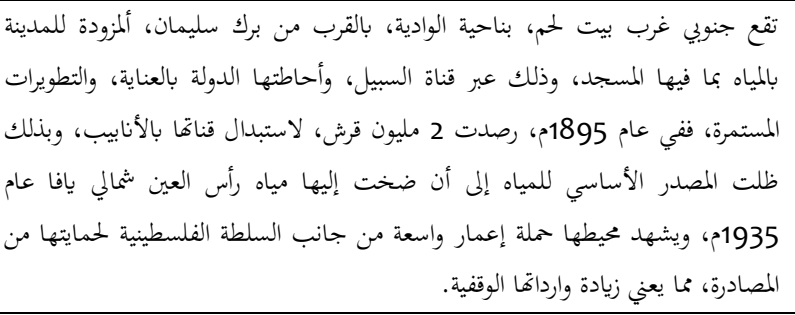 & 100 & البرك & .27 \\
\hline تقع بناحية جبل القدس، ولم نتمكن من التعرف على موضعها على وجه التحديد. & 100 & قرية كفر ناتا & .28 \\
\hline 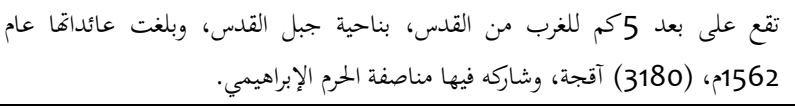 & 100 & قرية لفتا & .29 \\
\hline باشا بمشروعه العمراني عام 1622من متحعها بدقة، وآلت للخراب بفعل عدم استتباب الأمن، وشملها محمد & 100 & قرية القصور & .30 \\
\hline 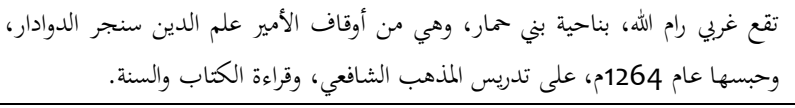 & 100 & قرية بيت نبالا & .31 \\
\hline 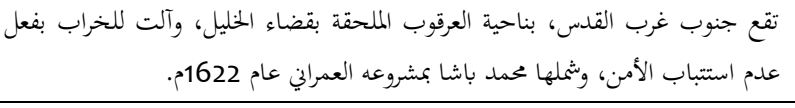 & 100 & | قرية & .32 \\
\hline تلمزودة شمالي الخليل، وآلت للخراب في القرن السابع عشر، وحبست على قناة السبيل & 100 & فضرية & .33 \\
\hline 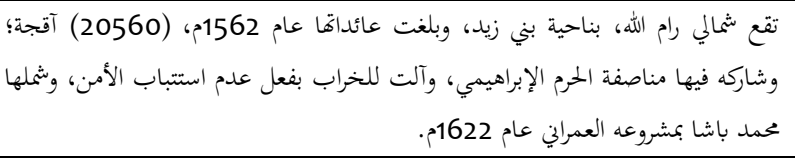 & 100 & قرية & 34 \\
\hline تلمزع جنوب شرق القدس، بالقرب من بيت ساحور النصارى، وشاركه فيها المدرسة & $\stackrel{\varphi}{?}$ & بيت & .35 \\
\hline تقع شمال غرب المخليل، بناحية العرقوب الملحقة بقضاء الخليل. & 100 & 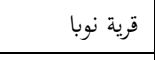 & $\cdot 36$ \\
\hline 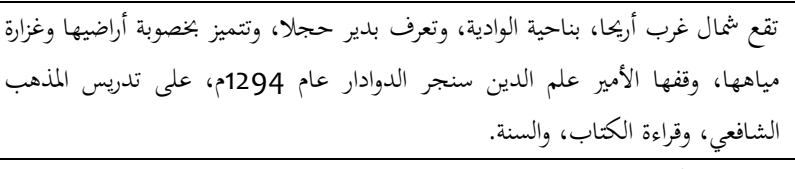 & 100 & قرية حجلا & .37 \\
\hline تالتي لا تتحمل البرد كالم أريحا، بناحية الوادية، وتتميز بخصوبتها، ووفرة مياهها وملائمة مناخها للنباتات & 100 & قرية نويعمة & .38 \\
\hline موسى القائم على طريق غرب القدس، بناحية العرقوب الملحقة بقضاء الحليل، وشاركه فيها مقام النبي & $(؟)$ & فوكين & 39 \\
\hline من مقع شمال الأردن على الضفة الجنوبية لنهر اليرموك، في قضاء عجلون، التابع للواء حوران، & 6.25 & قرية الطرة & 40 \\
\hline تقع ضمن أراضي قرية البيرة القائمة إلى الشمال الشرقي من رام الله، بناحية بني الحارث، & 100 & قرية سويكة & 41 \\
\hline
\end{tabular}




\begin{tabular}{|c|c|c|c|}
\hline 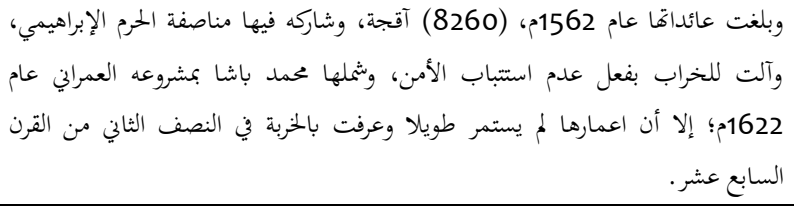 & & 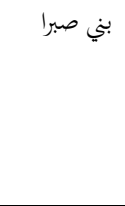 & \\
\hline تقع جنوبي سوريا في محيط مدينة بصرى التابعة للواء حوران. & 25 & قرية المشيرفة & .42 \\
\hline 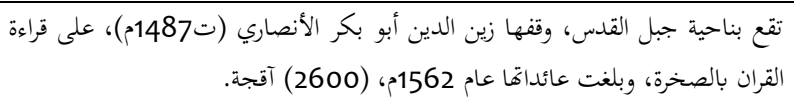 & 66.67 & مزرعة عين & .43 \\
\hline 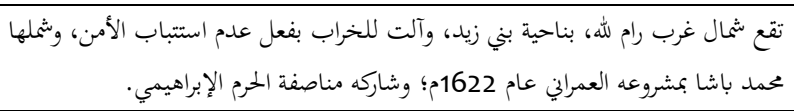 & 33 & غرية دير & .44 \\
\hline تقع شمال غرب طولكرم، بالقرب من قرية قاقون، وقفها علم الدين الدوادار عام 1294م، & 100 & قرية طبرس & .45 \\
\hline تقع شمالي القدس ضمن أراضي قرية كفر عقب، وقفها محمد عمران على ذريته، واشترط & 75 & مزرعة عطار & 46 \\
\hline تقع قبالة باب العامود بمنطقة المصرارة، وتمتد بمحيط خان بني سعد أو الإفرنج القائم قبالة & $33 \cdot 5$ & 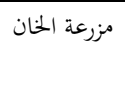 & 47 \\
\hline
\end{tabular}

\section{جدول 1: أراضي الموقوفة الأصلية 11}

يظهر أن 47 موقعا، حبست أراضيها على المسجد، وتركز 45 منها أي ما يوازي 96\% في لواء القدس و3.3\% من الـ340 موقعا الموقوفة في فلسطين، واقتصر قضاء طولكرم على طبرس، ولواء حوران على مشيرفة، والطرة، وضمت مساحات واسعة وصلت ذروتا بالعوجة يعكس حجم عائداتما السنوية، ومعظمها من الأوقاف الخيرية غير صحيحة، حسب قانون الأراضي وصي وصني العثماني 1858، التي تعود رقبتها للخزينة ورصدت منافعها للمسجد، وشاركه فيها المسجد الإبراهيمي بالخليل، 13 ويرجع حبسها للعهدين الأيوبي، والمملوكي، حيث وضع المسجدين في تشكيلة إدارية قوامها "نظارة الحرمين الشريفين". لقد تشكلت وزارة الأوقاف عام 1826م، واضطرب عملها بالغزو المصري لبلاد الشام عام 18311840م، وبانسحابه منها أناطت إدارة أوقاف وسط وجنوب فلسطين، 15 ب"مديرية عموم الأوقاف"، التي اتخذت من القدس مقرا لما16 وتتبعها مديريات أوقاف أقضية جنين، ونابلس، والخليل، ويافا، وغزة، وبير السبع 17 وتولت ضبط الأوقاف وتنظيمها، وبذلك خلصت 20 وقفا، اشتمل على 162 موقعا، من الفوضى، واعتبرةا أوقافا "مندرسة"، أو"مضبوطة" وأحالت عائداتها، للإنفاق على التعليم بأروقته، 18 كأوقاف "المارستان الصلاحي-أل-مضبوطة لجهة المعارف بالقدس الشريف"19 والمدرسة التنكزية، القائمة برواقه الغربي بباب السلسلة، واستخدمت مقرا للمحكمة الشرعية، وسكنا لقضاتما منذ عام 1516م، 
وحتى هاية الفترة العثمانية عام 1918م، ودارا للحاج أمين الحسيني 20 رئيس المجلس الإسلامي الأعلى 1921-1937، بصفته أعلى سلطة شرعية، ورثت الدولة العثمانية، برعايتها للأوقاف الإسلامية بما فيها أوقافه، 21 وقد أجرى القاضي الشرعي مداولات حثيثة مع الهيئات الإدارية والفنية لإعمارها عام 1659،

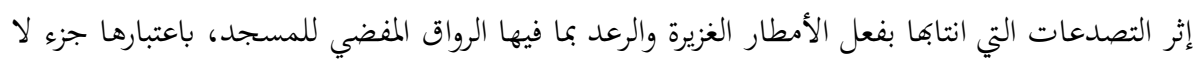
يتجزأ منه، انقطع التدريس فيها أو لم ينقطع، واشترط على المعماري أن لا يبيع فضلة الحجارة القديمة، والجديدة إلا بعد الانتهاء من اعمارها. 22 ومن الجدير بالذكر أن قضاة المحكمة الشرعية، والحاج أمين، قد ساروا بإقامتهم بالتنكزية على إلى خطى الهيئات الإدارية للمدينة إبان العهد المملوكي، وفي مقدمتهم السلطان فرج الذي أقام بها عند زيارته

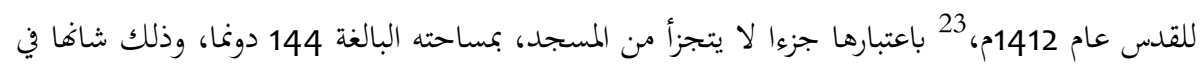
ذلك شان بقية أقسامه ومرافقه بصرف النظر عن مسمياقا، وما تضمنته وقفياما الخاصة من شروط فردية، والتي حرفت العديد من الباحثين المحدثين بنصوصها ورسومها عن جادة الصواب، فلم يلتفتوا للعلاقة الوثيقة بين أصوله وفروعه، والتي كانت وما تزال مسالة الربط فيما بينها، محط اهتمام هيئاته الإدارية إزاء ما يتربصه من مخاطر كتكريس الاحتلال للمفاهيم والمصطلحات الفردية، واستهدافه لساحاته الداخلية، ومطالبته بتطبيق قوانينه الخاصة بالأراضي عليها أسوة بغيرها من الأراضي الخالية من المباني.

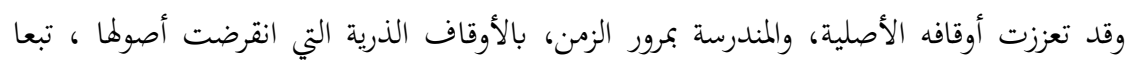
لشروط الواقف، كوقف محمد الناصري الشهير بأبي والي الذي حبس 13 قيراط، من أراضي كفر نعمة على نفسه، وذريته، ورصد ربعها بعد وفاته على قراءة القرآن وصحيح البخاري، وإن رصد جميع

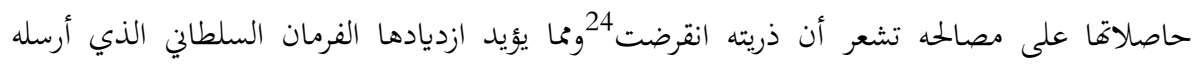

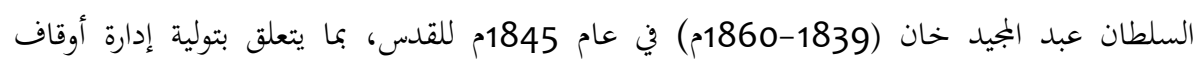
خاصكي سلطان، وأمانة مفتاح كنيسة القيامة، ويشير بان "وقف خاصكي سلطان طاب ثراها الواقع في القلس الشريف، وهو من الأوقاف الملحقة بنظاة أوقاف ملوكانيتي....-وعلى المتولين-...أن يليروا هذا الوقف إدارة حسنة....وأن يجروا المحاسبة في كل سنة بمعرفة الشرع، ويمضوا ويختموا دفاتر

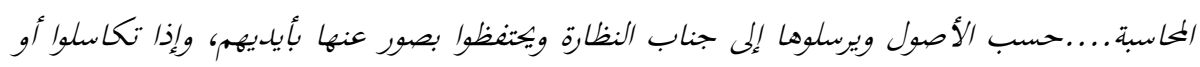

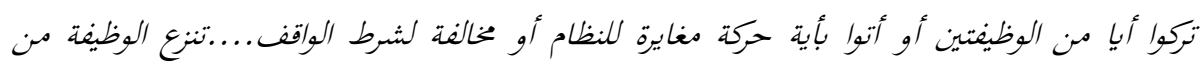
أيديهم، وتعطى لغيرهم" . 25 وبموجب هذه الشروط، وتنسيب ناظر الأوقاف منحوا البراءة السلطانية، 26 كما أن الحاج أمين الحسيني قد اشترى مساحات واسعة من الأراضي المهددة من الحركة الصهيونية، ورصدها عليه ما بين عام 1921-1948م، وتتضح أوقافه الملحقة ببيانات الجدول 2. 


\begin{tabular}{|c|c|c|c|}
\hline 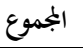 & المواقع الموقوفة & جهة الوقف & 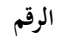 \\
\hline 38 & 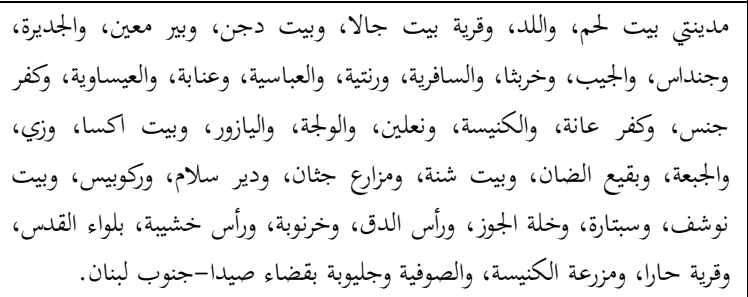 & تكية خاصكي بالقدس & .1 \\
\hline 10 & 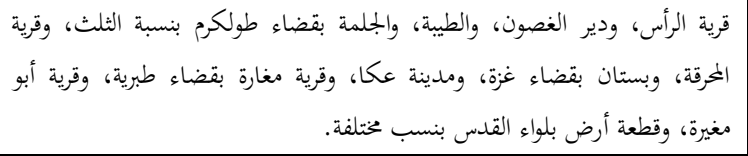 & رباط السلطان قلاوون & .2 \\
\hline 54 & 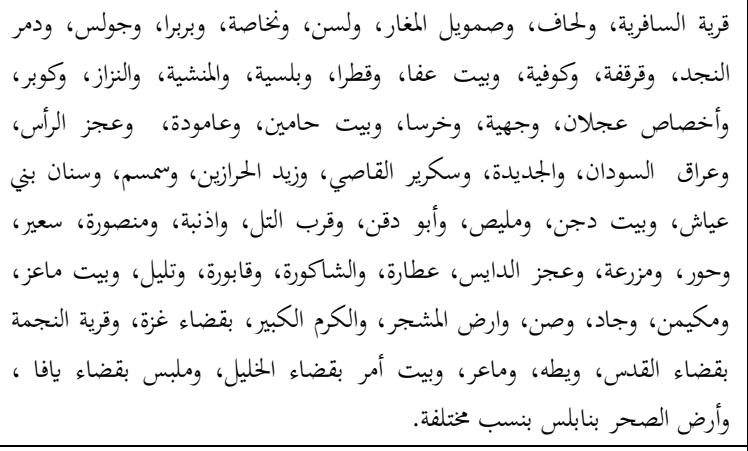 & المدرسة الأشرفية & 3 \\
\hline 1 & قرية صور باهر. & المدرسة الباسطية & .4 \\
\hline 2 & قرية كفر قرع، وجزء من طولكرم. & المدرسة العثمانية & .5 \\
\hline 2 & قريتي حرستا، وكوم التجار في مصر. & المدرسة البلدية & .6 \\
\hline 2 & قرية شويكة، وجزء من طولكرم. & المدرسة الفارسية & .7 \\
\hline 1 & قرية بيت لقيا. & المدرسة النحوية & .8 \\
\hline 1 & ارار الزرد خانة في مدينة القدس. & 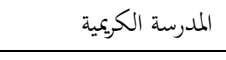 & .9 \\
\hline 5 & وقرية تقوع بقضاء بيت لحم، وكوفية، وبيت زيتون بقضاء غزة، ومدينة طولكرم، & المدرسة الجوهرية & .10 \\
\hline 2 & قرية عين قينيا، وجنينة في مدينة القدس. & المدرسة التنكزية & .11 \\
\hline 6 & الرملة بنسب شيتلفة وحبلة، وكفر سابا، وكفر جنس، وجيوس بقضاء طولكرم وبريكة & المدرسة الزمنية & .12 \\
\hline 2 & مزرعتي باطن الجمل، وظاهر الجمل بظاهر القدس. & المدرسة الخاتونية & .13 \\
\hline 10 & 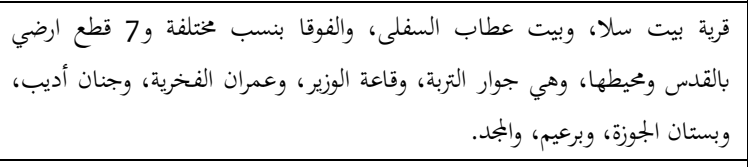 & 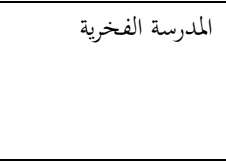 & .14 \\
\hline 7 & 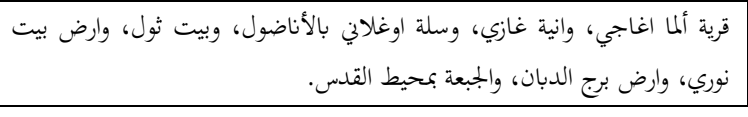 & المدرسة الطيلونية & .15 \\
\hline
\end{tabular}




\begin{tabular}{|c|c|c|c|}
\hline 4 & بنسب مختلفة. بيت ساحور الواد، وعين جاوية، ومزرعتي مران، وخان بني سعد بمحيط القدس & المدرسة المزهرية & .16 \\
\hline 2 & قريتي أرحيل، واغاج بولاية حلب. & المدرسة الغادرية & .17 \\
\hline 5 & الأكراد في لبنان. صفافا، والمنجكية، والبنا بمحيط القدس، ومدينة طرابلس، وقرية حصن & المدرسة الأرغونية & .18 \\
\hline 1 & قرية دير بزيغ. & المدرسة الملكية & .19 \\
\hline 4 & 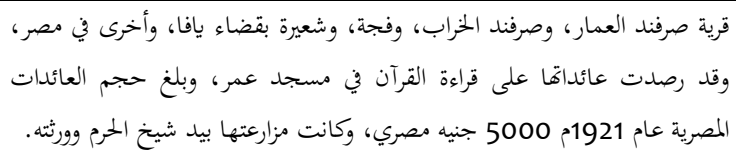 & وقف سنان باشا & .20 \\
\hline 2 & يوميا بعد صلاة العصر. أرضرى بأرض البقعة بالقدس، وحبست على خمسة قراء بالصخرة & وقف عائشة الرومية & .21 \\
\hline 162 & & الجموع & \\
\hline
\end{tabular}

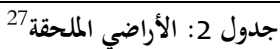

وبموجب ذلك، فقد نعم المسجد ومرافقه المؤلفة من المدارس والأربطة وتكايا بأوقاف لا ينافسه فيها

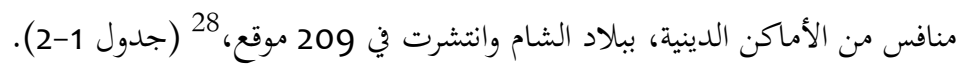

المسقفات: المباني ومرافقها القائمة بالمدن وأطرافها، وحبست على مصالحه، ويشملها الجدول 3.

\begin{tabular}{|c|c|c|c|}
\hline الجموع & الملاحظات & النوع & الرقم \\
\hline 48 & 34 دارا بحارة الشرف، و5 بالرباط المنصوري، و1 بخط المنارة، و1 بمحلة الجوالدة، و1 بوقف الغادرية، و1 بوقف التنكزية، و5 برباط الناظر بالقدس، و5 بححلة الحبلة بنابلس. & الدور & .1 \\
\hline+124 & 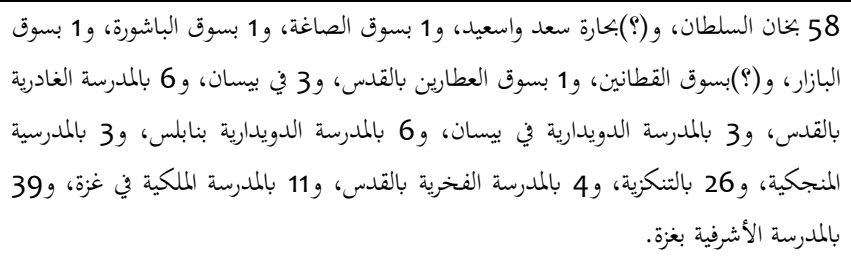 & الدكاكين & .2 \\
\hline+11 & إسطبل بوقف الصخازن الدقاقين، و5 بالمدرسة الكريمية بباب الخليل، و3 أقبية وصهريجين بوقف الناظر، و1 & والمخازن & 3 \\
\hline 11 & 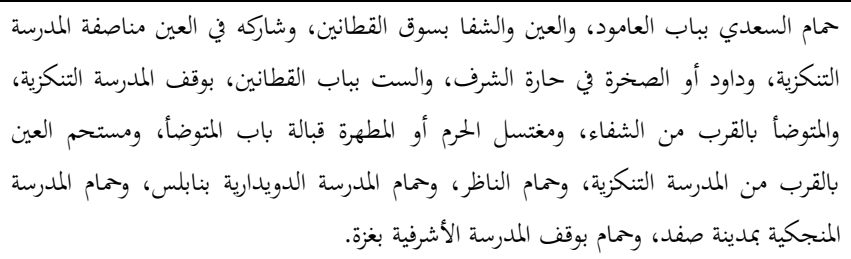 & الحمامات & 4 \\
\hline 7 & خار الفخرية القدس، وخان السطان، والخضر، والفحم، والشعارة، والتجار أو الخواجات، داخل القدس والإفرنج & الخانات & .5 \\
\hline
\end{tabular}




\begin{tabular}{|c|c|c|c|}
\hline 23 & 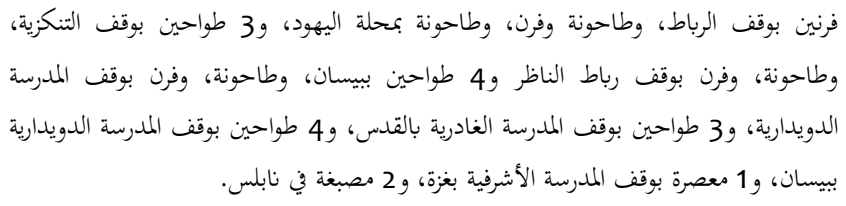 & 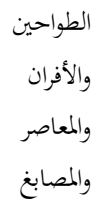 & .6 \\
\hline 3 & بغزة. لمنصوري، والبصير بباب الناظر بالقدس، ومشفى الأمراض العصبية بوقف المدرسة الأشرفية & والمثافية & 7 \\
\hline 19 & 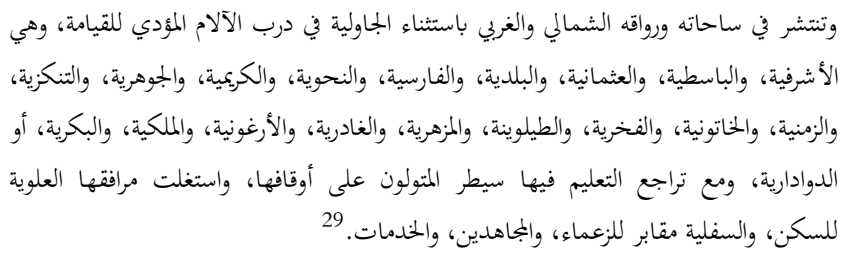 & 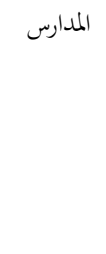 & .8 \\
\hline 2 & تلكية خاصكي سلطان بعقبة السرايا، ودار الست مقابل التكية، وتعرف اليوم بدار الأيتام & 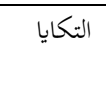 & 9 \\
\hline 1 & بحارة اليهود بالقدس. & المسلخ & .10 \\
\hline 5 & قاعة في محلة سوق التركمان بغزة بوقف المبعدية بوقف المدرسة الأسعردية، و1 قاعة بوقف المدرسية المنجكية بالقدس، و2 & والخانقاه & .11 \\
\hline 1 & بوقف المدرسة الدويدارية بنابلس. & 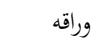 & .12 \\
\hline$\varphi$ & بموعة مسقفات (؟)بدمشق. & $\varphi$ & .13 \\
\hline & 255+المسقفات غير المبينة وفي مقدمتها دمشق. & 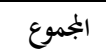 & \\
\hline
\end{tabular}

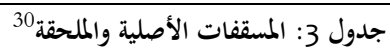

ونلاحظ أن مسقفاته كانت في تزايد مستمر، نظرا لتحول الأوقاف الذرية إلى خيرية تبعا لشروط الواقفين، ورفدها بمسقفات جديدة أجازت القواعد الشرعية، والقانونية وقفها لقيامها على الأراضي المملوكة داخل حدود القرى والمدن، وسهولة ويسر متابعة أحوالها العامة لقربها من المؤسسات الأهلية والحكومية، وقوة الوازع الديني لدى الرعية، وحرصها على عدم المساس بها طلبا للأجر والثواب، وهو ما جعل عائداها أكثر استقرارا من الأراضي، التي تأثرت بالعوامل الطبيعية، والبشرية بصورة أكبر، فاضطراب عائدات الوقف بناحية بني زيد، بسبب الحروب الأهلية، وغارات القبائل، 31 لم يوازيه تراجع بعائدات خان السلطان، بسبب الحركة الاقتصادية النشطة التي شهدقا المدينة، نتيجة للنمو السكاني، وتوافد الزوار وزيادة الطلب على السلع، بصرف النظر عما تشهده مناطق الإنتاج، مما يفسر ارتفاع عائداته بصورة

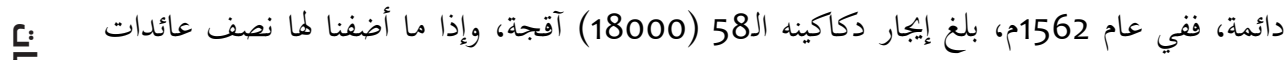

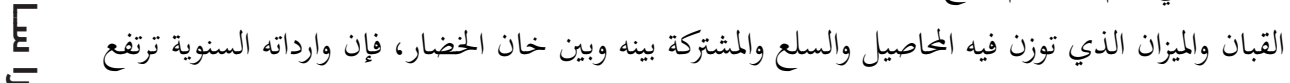
อ

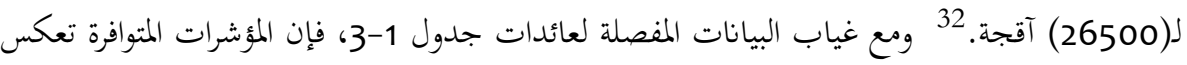
إلى حد كبير ضخامة حجمها، ومن شواهدها الدالة بيانات جدول 4. 


\begin{tabular}{|c|c|c|c|c|}
\hline ملاحظات & العائدات/آقجة & 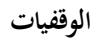 & الجهة & 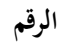 \\
\hline عامرة. & 231503 & 35 & المسجد الأقصى & .1 \\
\hline 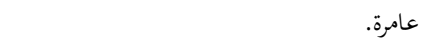 & 156510 & 18 & تكية خاصكي سلطان & .2 \\
\hline 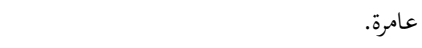 & 4600 & 4 & المدرسة الطيلونية & $\cdot 3$ \\
\hline عامرة ولم تسجل. & - & 4 & المدرسة الزمنية & .4 \\
\hline عامرة ولم تسجل. & - & 5 & المدرسة الغادرية & .5 \\
\hline 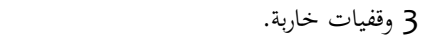 & 3126 & 9 & المدرسة الفخرية & .6 \\
\hline 8 وقفيات لم تسجل. & 17799 & 12 & المدرسة الجوهرية & .7 \\
\hline 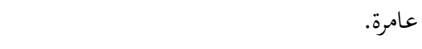 & 8564 & 1 & المدرسة الباسطية & .8 \\
\hline 7 وقفيات لم تسجل وطواحين عين قينية خاربة. & 19480 & 12 & المدرسة التنكزية & .9 \\
\hline 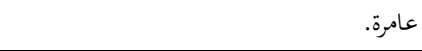 & 4600 & 2 & المدرسة المزهرية & .10 \\
\hline 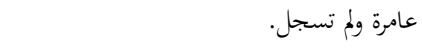 & - & 1 & المدرسة الأسعردية & .11 \\
\hline عامرة و16 وقفية لم تسجل. & 350 & 17 & الرباط المنصوري & .12 \\
\hline عامرة ولم تسجل. & - & 11 & رباط البصير & .13 \\
\hline +عائدات غير مسجلة. & 446532 & 131 & الجموع & \\
\hline
\end{tabular}

جدول 4: عائدات أوقاف المسجد الأقصى وملحقاته لعام 1562م333

يظهر أن عائداتا بلغت نحو نصف مليون آقجة، واستحوذت الأوقاف الأصلية على 52\% من مجملها علاوة على الوقفيات التي لم تسجل، بالرغم من عمارتما، مما يشعر أن موعد تحصيلها لم يستحق عند التسجيل، وتتضح أبعادها مع استقرار سعر الصرف، والقيمة الشرائية للعملة من السلع، والخدمات. 34

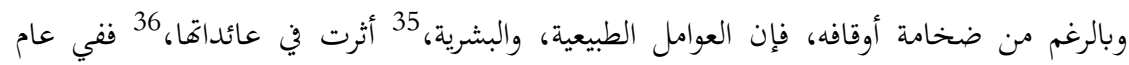
1622م، الخفض زيته بناحية بني زيد من 110-52 قنطارا، نتيجة لخرابها، 37 وفي عام 1714م نفذ فئ بالكامل، ولم يستطع صندوقه توفير مشترياته، 38 مما يعني أن الظروف الصعبة قد ألقت بظلالها ليس على مصول الزيتون وحسب، بل على جميع فعاليات الحركة الاقتصادية، كما هو الحال في موسم عام

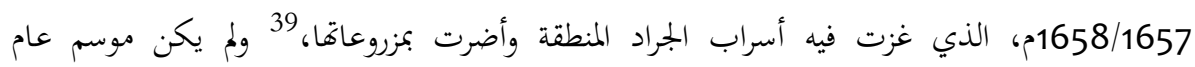
1659/1658م، أفضل حالا بالرغم من هطول الأمطار مبكرا وهبوب العواصف، وتشكل الصقيع، والتي قضت على بيوضه وفراخه، وأجبرت أسرابه على الرحيل، وعززت المخزون المائي، ووضعت حدا لانتشار

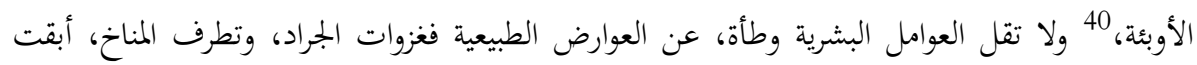
على أصول الأشجار التي بمقدورها بحديد نشاطها، بينما اضطراب حبل الأمن قرى ناحية بني زيد، وأحالها إلى خرائب بائدة، 41 ناهيك عن تطاول بعض المتولين، والجباة، والكتاب، والنواطير على رقبتها، ومنافعها، وسجلوها متثلكات خاصة بأسمائهم. 42 
الأوقاف المنقولة: أقر فقهاء الأحناف حبسها، استنادا لوقف خالد بن الوليد للدروع في سبيل الله، وإقرار النبي صلى الله عليه وسلم له، 43 ويشملها جدول 5.

\begin{tabular}{|c|c|c|c|}
\hline 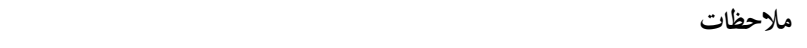 & $\%$ & 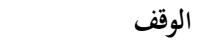 & 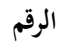 \\
\hline 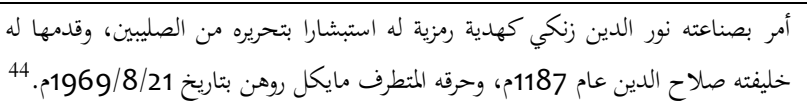 & 100 & المنبر & .1 \\
\hline 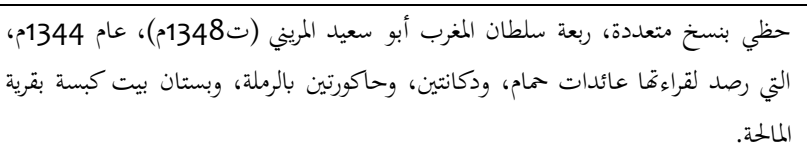 & 100 & المصاحف وربعامات45 & .2 \\
\hline 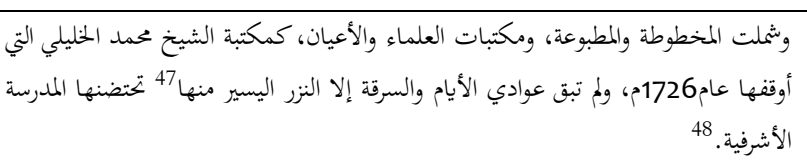 & 100 & الكتب & $\cdot 3$ \\
\hline كيل الغلال الواردة للقدس، وبلغت عائداتها عام 1562م، (8000) آقجة. 49 & 100 & 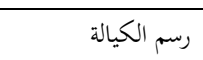 & .4 \\
\hline وبلغت عائداته مع سوق الخضر عام 1562م، (17000) آقجة. 50 & 100 & 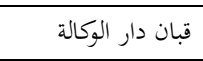 & .5 \\
\hline جبيت تحت اسم "رسم قبان". 51 & 100 & قبان دار الخضر & .6 \\
\hline وتؤخذ بباب كنيسة القيامة، وبلغت عائداتا عام 1562م، (3000) آقجة. 52 & 100 & 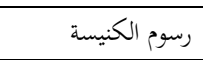 & .7 \\
\hline المصنع بالقدس، والمصدر إلى مصر، وبلغت عام1562م، (3685) آقجة. & 100 & 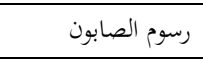 & .8 \\
\hline الوافدين للقدس، الموظفين، وبلغت عائداتحا عام 1562م، (4000) آقجة. & 100 & مصول المجاورين & .9 \\
\hline يخفظ بالصخرة، وبلغت عائداته عام1562م، (1200) آقجة. 53 & 100 & صندوق النذور & .10 \\
\hline يدفعها أهل الذمة بقرية بيت ريما، وعين عريك، وبني فضيل، وبلغت عائداتها عام & 100 & الجزية & .11 \\
\hline الحصر، والسجاد. & 100 & 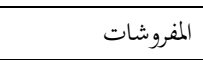 & .12 \\
\hline مشروعيتها. & 100 & النقود & .13 \\
\hline وتستخدم للطبخ، وغلي المياه بالتكايا، والحمامات. & 100 & 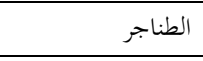 & .14 \\
\hline 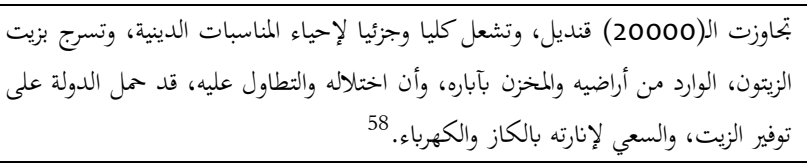 & 100 & الأسرجة والقناديل & .15 \\
\hline بتذاكر خاصة بإشراف المتوائف الوافدة لزيارة كنسية القيامة، ورصدت والكاتب، وأمين المفتاح، والصيرفي، وإبماره، وقراءة القرآن، وبتجى. & 100 & 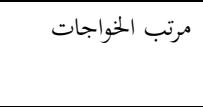 & .16 \\
\hline
\end{tabular}


وفعالياتما، بدخول طاقة الكاز والكهرباء لميادين العمل في أواخر العهد العثماني، وبذلك تنحت قناديله وترياته المسرجة بالزيت والشمع، جانبا لسرجها بالكاز، والمولدات الكهربائية. 61

\section{ثانيا:الصُوَّةُ}

قطعة القماش التي تفرد وتوضع بوسطها النقود، ثم تعقد وتخزم أطرافها، وجمعها صُرَرٌ، 62 وذلك بخلاف الكيس الذي استخدم كوحدة عد عثمانية للنقود قوامها 500 قرشا63، وفي الاصطلاح النقود التي يتبرع بها المسلمون ويرسلوها إلى مدينة القدس، لتوزيعها على خدمة المسجد وبجاوريه رجالا ونساء فقراء. وأغنياء64 وتبعا لاتحاهاقا تألفت من أربع صرر هي: اليمنية، والمصرية، والعراقية، والرومية، وتميزت الأخيرة، بجمعها من العاصمة اسطنبول، ومساهمة السلطان فيها، ولم يتوقف إرساها سنويا إلا عام

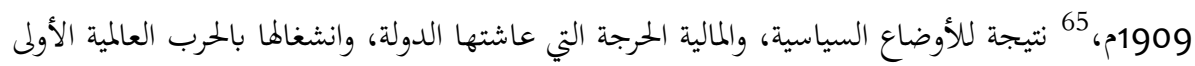
التي اشتعل فتيلها عام 1914م، الأمر الذي يفسر توجيه نداءات الاستغاثة التي وجهتها الدوائر الإسلامية

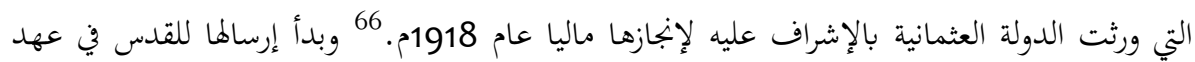
السلطان بايزيد (ت1388م)، 67 وبفتح القسطنطينية عام 1453م، أرسلت من اسطنبول، ونسبة لها عرفت ب"الإسلامبولية"، وبانضواء الشام، تحت سلطاها عام 1516م، أحاطها العثمانيون بهالة من الاحترام، والتقدير للتأكيد على وراثتهم للخلافة، وزعامتهم العالم الإسلامي، وأحقيتهم بخدمة الأماكن المقدسة، وهو ما أدخلها مرحلة متقدمة من التنظيم والتقدم، فأنيطت بأمين الصرة، واقترن إرسالها بمسيرة موكب الحج من اسطنبول، ويسير بركبه حجاج العاصمة وولاياتا الأوروبية، والأناضول، وروسيا، وتتجمع

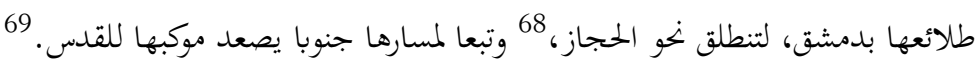

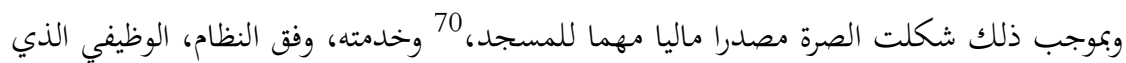
حتمته التقاليد، والأعراف المتوارثة، وحصرها في عائلات مقدسية محددة، ولم تسمح بدخول أخرى تعمل على منافستها ماديا، ومعنويا، وبلغ عددهم 1000 موظف، برئاسة شيخ الحرم وينتظمون بمشيخات

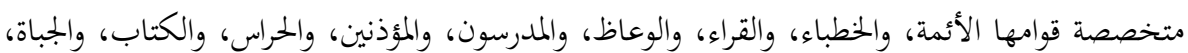
وأمناء الصناديق، والمكتبات، والفراشين، وعملا بنظام الصرة، تقاضوا مستحقاقم النقدية والعينية من أمينها، بما اشتملت عليه من النقود والخنلع، وأحيل صرف حصصهم التموينية، من اللحم، والخبز، للعمارة العامرة أو تكية خاصكي سلطان زوجة السلطان سليمان القانوني، وعلى نسقها وزعت مدخرات"الصرة المصرية الواردة في كل سنة من مصر المحمية لأهالي القدس الشريف"، 71 وكان حجمها في تزايد مستمر نظرا لقوة العاطفة الدينية، وارتفاع عدد السكان، وتنامي قواهم الاقتصادية، وتبدل أسعار الصرف 
والسلع، والخدمات ففي عام 1718م، بلغ ما حمله للقدس 2480 ليرة، وارتفع في عام 1756م، لـ3800

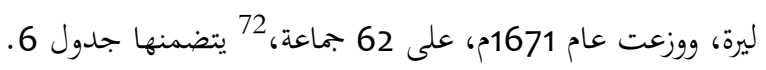

\begin{tabular}{|c|c|c|c|}
\hline 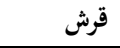 & الحدمة & 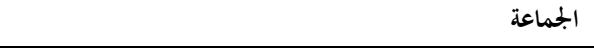 & 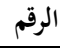 \\
\hline 76 & 4 & مفتي الحنفية وشيخ الحرم. & .1 \\
\hline 56 & 6 & الخطباء. & .2 \\
\hline 156 & 12 & أئمة الصخرة. & 3 \\
\hline 55.5 & 38 & المصدرين والمعرفين. & .4 \\
\hline 27 & 27 & خدمة الصخرة. & .5 \\
\hline 20 & 20 & خدمة الأقصى. & .6 \\
\hline 32 & 32 & 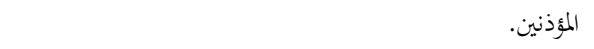 & .7 \\
\hline 37 & 32 & الكتاب. & .8 \\
\hline 25 & 25 & 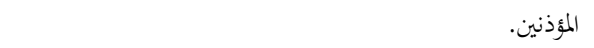 & .9 \\
\hline 20 & 20 & 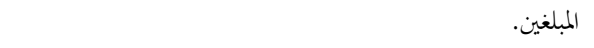 & .10 \\
\hline 13 & 12 & 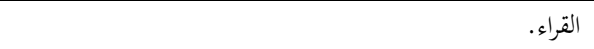 & .11 \\
\hline 7.5 & 15 & قراء الجمعة. & .12 \\
\hline 8 & 8 & جباة الأوقاف. & .13 \\
\hline 162.15 & 91 & قراء الأجزاء بالصخرة على روح السلطان القانوني. & .14 \\
\hline 1460.15 & 119 & صلحا وفقرا المجاورين ومفتي الشافعية والإشراف. & .15 \\
\hline 400 & 33 & قراء الأجزاء على روح السلطان سليم. & .16 \\
\hline 243 & 35 & قراء الأجزاء على روح والدة السلطان. & .17 \\
\hline 52 & 52 & 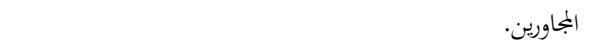 & .18 \\
\hline 55 & 55 & حي باب القطانين. & .19 \\
\hline 64 & 64 & حي باب حطة. & .20 \\
\hline 22 & 22 & الأروام المجاورين بحجرات وعمارة تكية خاصكي سلطان. & .21 \\
\hline 22 & 22 & حي باب العامود والغوانمة. & .22 \\
\hline 20 & 20 & حي باب الثلاثة وخط النبي داود. & .23 \\
\hline 17 & 17 & حي باب حطة التحتاني. & .24 \\
\hline 9 & 9 & حي الشرف. & .25 \\
\hline 7 & 7 & حي الخوالدة. & .26 \\
\hline 13 & 13 & حي السرسة. & .27 \\
\hline 18 & 18 & خدمة وبجاوري مقام داود. & .28 \\
\hline 10 & 10 & شيخ نصرة الإسلام أبو المدى. & .29 \\
\hline 9 & 9 & الشيخ أبي المدى بن داود وشيخ محيا الرسول صلى الله عليه وسلم. & .30 \\
\hline 11 & 11 & فقراء الشيخ الصامت. & .31 \\
\hline
\end{tabular}




\begin{tabular}{|c|c|c|c|}
\hline 11 & 11 & محمد العربي. & .32 \\
\hline 8 & 8 & البماورين بالرباط المنصوري. & .33 \\
\hline 9 & 9 & رباط البصير. & .34 \\
\hline 3 & 3 & رباط بيرام جاوش. & .35 \\
\hline 6 & 6 & رباط قاسم وحوش العيد. & 36 \\
\hline 7 & 7 & بجاوري المدرسة الرومية والجوهرية. & .37 \\
\hline 17 & 17 & عقبة البيك وباب العامود. & .38 \\
\hline 9 & 9 & خدام الجامع العمري في حي الهنود وزاويتهم. & .39 \\
\hline 15 & 15 & زاوية الهنود الملطاني. & .40 \\
\hline 13 & 13 & زاوية الهنود بباب الساهرة. & .41 \\
\hline 20 & 20 & المغاربة وحي الريشة. & .42 \\
\hline 5 & 5 & محافظي قلعة القدس القائمين عند التوزيع. & .43 \\
\hline 17.5 & 35 & نساء فقيرات. & .44 \\
\hline 18 & 57 & نساء حي القطانين. & .45 \\
\hline 17 & 33 & نساء باب حطة. & .46 \\
\hline 12 & 24 & نساء حي الريشة والحوالدة. & .47 \\
\hline 4 & 8 & نساء خط باب داود. & .48 \\
\hline 2.5 & 5 & نساء عقبة الست. & .49 \\
\hline 6.5 & 12 & نساء حي الغوانمة. & .50 \\
\hline 8.5 & 17 & نساء حي باب العامود. & .51 \\
\hline 9 & 18 & نساء سلطانية والمنجكية. & .52 \\
\hline 8 & 11 & نساء رباط البصير ورباط الحاجة فاطمة. & .53 \\
\hline 6 & 12 & نساء رباط الحاج قاسم. & .54 \\
\hline 10.5 & 21 & نساء المدرسة الميمونية والزوية السلطانية. & .55 \\
\hline 7.5 & 15 & ن مساء المولوية. & .56 \\
\hline 7 & 14 & نساء رباط كرد وسدنة العمري. & .57 \\
\hline 24 & 28 & نساء باب حطة العلوي. & .58 \\
\hline 7 & 14 & نساء رباط مكي والمدرسة الحنفية. & .59 \\
\hline 6 & 12 & نساء الهنود الملطاني والسليماني. & .60 \\
\hline 7 & 14 & نساء رباط (؟) مع رباط السلطان. & .61 \\
\hline 7 & 14 & نساء مقام داود البجاورات. & .62 \\
\hline 3498.30 & 1345 & الجمموع & \\
\hline
\end{tabular}

جدول 6: الأوقاف المنقولة73

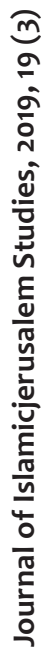


توزعت الصرة على 62 جماعة، ضمت 1345 شخصا، وفي مقدمتهم مشيخة الحرم وموظفيه، ومجاوريه،

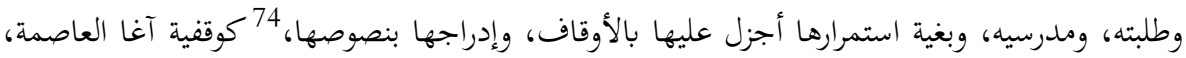
التي اشترط فيها حبس 108 قروش، لقراءة عروسين من القران بالسنة، وإهداء ثوابها للواقف، ونصب 15 قنديلا، بأروقته، وتخصيص 15 قرشا، لزيتها و 5 قروش لسارجيها، و15 قرشا، لشيخ الحرم، لقاء نظارته

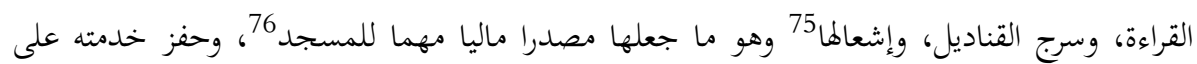
التعليم، 77 للحفاظ على وظائفهم وامتيازاهم 78 كآل الحسيني الذين سيطروا على مشيخة الحرم، 79 ونقابة

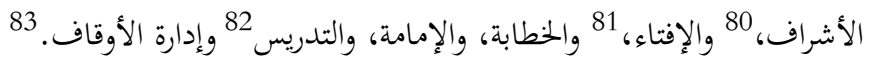

ثالثا: الحزينة تعد الخزينة المصدر المالي الثالث للإنفاق على المسجد، 84 بالتعاون مع وزارة الأوقاف، 85 وغالبا ما شملت صرف رواتب موظفيه الـ 1000، ${ }^{86}$ وسد عجز صندوقه، ومما يؤيد ذلك الإشارات الصريحة التي زودتنا بها سجلات محكمة القدس الشرعية عام 1714م، عندما أكدت أنه "يهتاج إلى تنوير، وليس ببير

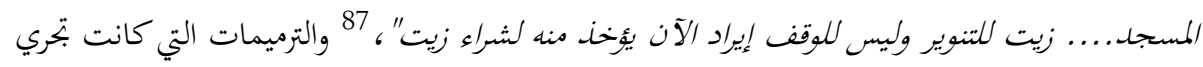

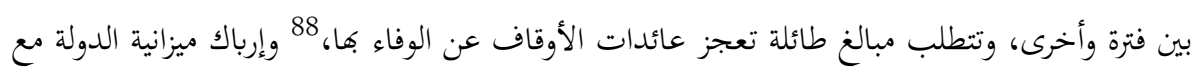
ارتفاع قيمة العجز. 89 وكانت أعمال الصيانة، والترميم بالمسجد تحتمها العوامل الطبيعية، والبشرية المؤثرة في نسيجه العمراني، ومرافقه، ومقتنياته كالزلازل، وتقلبات الطقس، والحرارة، والأمطار، والصقيع، وتراكم الثلوج، والعواصف الرعدية، والتشققات، والدلوف، وانسداد فتحات التصريف، ونمو الفطريات، وتسوس

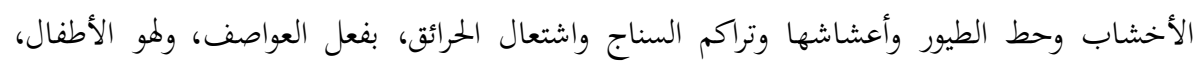

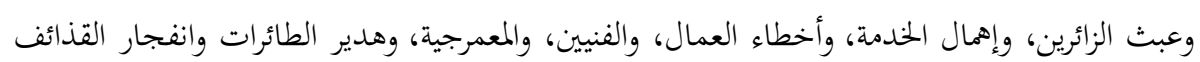
التي استخدمت لأول مرة، بالحرب العالمية الأولى، مما يفسر وقف أراضي قرية العوجة البالغة 152000 دونم، على مصالح إعماره، واستعداد الخزينة لتغطية عجز صندوقه. 90 لم تظهر آثار تنظيمات وزارة الأوقاف مباشرة بتشكيلها عام 1826م، 91 بفعل احتلال محمد علي باشا والي مصر، لبلاد الشام عام 1831م وخروج المسجد من إشرافها، 92 والذي حاول خلال حكمه بكام ضبط أوقافه وتنظيمها، أسوة بما قام به في مصر بهدف تعزيز موارد الخزينة، والحد من نفوذ الزعامات : 
من فلسطين، وما يتعلق بمؤسساتا من أوقاف في الولايات العربية والإسلامية، 97 ولم تتوان عن الاستفادة من التنظيمات المصرية، فعمدت إلى ضبط عائداتا ومصروفاتا السنوية، وإحالة 12 وقفا، تعود للمدارس، والمؤسسات الوقفية المنتشرة في محيطه، حيث تعطل العمل بتلك "الأوقاف المندرسة"، وتحويل عائداتحا لصندوقه، للإنفاق على مصالح التعليم في أروقته. 98 وتعززت إجراءاتا بتطور وسائل المواصلات والاتصالات العاملة بين اسطنبول والقدس، كالسفن البخارية، 99 والسكك الحديدية، والسيارات، 100 والتلغراف، والهاتف. إن عمليات الإعمار بمساحته الممتدة إلى 144 دونما، كانت تعتمد على ما يقدمه الفنيون، من تقارير، 102 وما يرفعه الخدمة، والأهالي، من عرائض للدولة تحثها على ذلك، 103 وبدأت أولى عملياتها بدخول القدس تحت الحكم العثماني عام 1516م، عندما وعد السلطان سليم الأول، عند اجتماعه بالأهالي، بإعمار السور، لحمايتها من تعديات العربان، واللصوص، والحيوانات المفترسة، وفي عام 1536م، شرع القانوني (ت1566)، بإنفاذ ما وعد به والده، وجاء ذلك في إطار حملته العمرانية الواسعة، التي انتدب للإشراف عليها مهندس قصره الخاص سنان باشا، وشنملت أروقته الداخلية بما فيها قبة الصخرة، وجداره الجنوبي والشرقي، الذي يشكل جزءاً لا يتجزأ من السور الخارجي للمدينة، واستمر ذلك خمس سنوات، ورصد على مصالحه ضرائب مصر، 104 وكان فاتحة عهد جديد من الأعمال العمرانية، التي

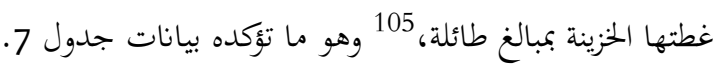

\begin{tabular}{|c|c|c|c|}
\hline ملاحظات & قرش & العام & الرقم \\
\hline رصد على مصالحه ضرائب مصر لأربع سنوات. & - & 1538 & .1 \\
\hline ترميمات مختلفة. & 7600 & 1670 & .2 \\
\hline & 173770 & 1689 & 3 \\
\hline بما فيها تكاليف النقل من ميناء يافا 36687 قرشا. & 301386 & 1709 & 4 \\
\hline وشمل إعمار حمام الشفا والعين والنبي داود. & 201330 & 1727 & .5 \\
\hline شاركه فيها جميع الأماكن الدينية. & 6529280 & 1780 & .6 \\
\hline وفرتحا خزينة ولاية عكا في ظل حكم سليمان باشا العادل (1805-1818). & 2000000 & 1817 & .7 \\
\hline 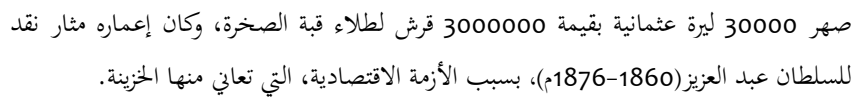 & 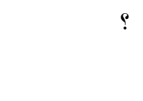 & 1874 & .8 \\
\hline
\end{tabular}
جدول 7: تفقات الحزينة

وكانت أعمالها بتحي بإشراف الهيئة المنتدبة من اسطنبول، والحاكم الإداري، والقاضي الشرعي، ومشيخة

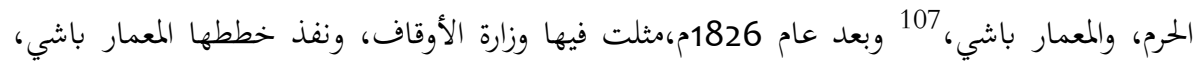
مستعينا بعدد من الفنيين، والعمال المهرة من الحجارين، والنقاشين، والبنائين، والمبلطين، والرسامين، 
والخطاطين من المسلمين، والذمة من رعايا الدولة108 ناهيك عن جهاز "الخفيه"، والمباحث السرية الذي كان يرسل بتقاريره للسلطان، واستطاع من خلاله عام 1576م، أن يعرف بأن حاكم القدس قد نقل ألواح الحديد، والفولاذ، والرصاص، والكربون، والرخام المتبقية من إعمار السلطان سليمان القانوني

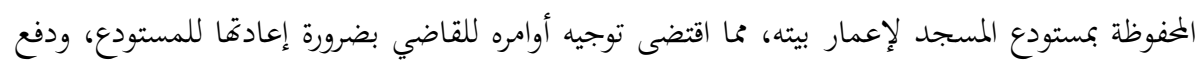
ثمن ما استخدم منها.

النتائج

أولا: امتلك المسجد مصادر مالية غزيرة الإنتاج، لا ينافسه فيها منافس من الأماكن الدينية في بلاد الشام.

ثانيا: امتدت المشاريع العمرانية، والزراعية، والحرفية إلى أراضيه، الموقوفة الصحيحة، وغير الصحيحة، مما

$$
\text { يعني ارتفاع معدلات وارداته. }
$$

ثالثا: عجزت مصادره المالية عن الوفاء بكافة مصاريفه، ونفقاته، مما حتم على الخزينة العثمانية سد

عجزها في مجالات الزيت، والإنارة، والنهوض بكافة أعمال العمارة والترميم مما أثقل كاهلها. رابعا: تعرضت أوقافه المنقولة، وغير المنقولة لتعديات بعض العامة، والخاصة من المتصرفين، والمتولين وغيرهم، مما اقتضى تدخل الجهات المشرفة عليه، وتشديد رقابة الدولة، وإن تمسك خدمته بالنظام الوظيفي المتوارث قد حرمه من مشاركة الكفاءات والخبرات العملية الخارجية القادرة على لى الوفاء بإدارة موارده ومصروفاته.

خامسا: إن عمارته الدائمة بالأرض، واستمراره بأداء رسالته الروحية، والحضارية السامية، دليل على أن حقوقه بأوقافه المنقولة وغير المنقولة ثابتة غير قابلة للتقادم بتقلب الدول والأزمان، ومثبتة بالشرائع والقوانين، والأعراف، والوثائق، والنصوص، ومن ونس حقه المطالبة بها بالمحاكم المحلية والدولية. سادسا: لم يقدم صندوقه على استثمار فائض عائداته التي يقوم على حفظها لحين الطلب، ليس بهدف تنميتها والاستفادة من أرباحها فحسب، بل بقصد حمايتها من تقلبات أسعار الصرف، وتآكل قيمتها الشرائية، وارتفاع أسعار السلع، والخدمات اللازمة له في المستقبل.

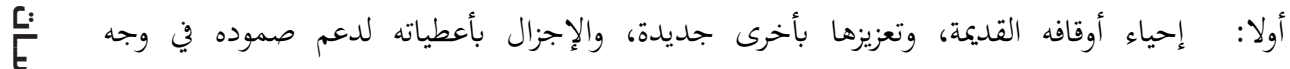
它 التحديات الطبيعية والبشرية التي تعترض سبيله حاضرا ومستقبلا. 
ثانيا: المطالبة بجقوقه في أوقافه المنقولة وغير المنقولة الثابتة، وغير القابلة للتصرف والثقادم، أسوة بغيره

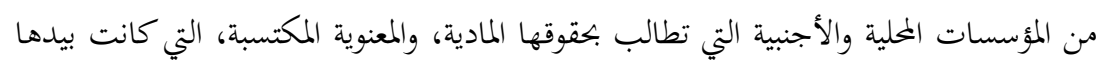

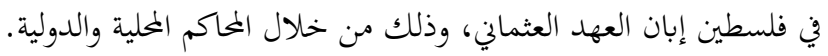

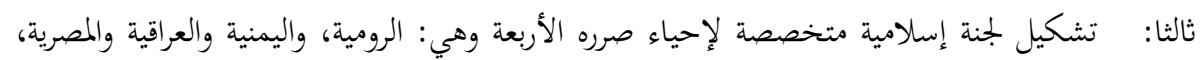

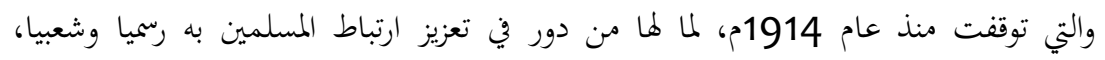
وضمان مصدر دخل غزير له، قادر على الوفاء باحتياجاته، وعمرانه حاضرا ومستقبلا.

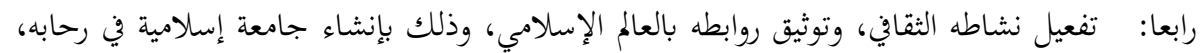

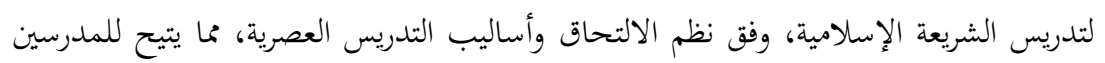

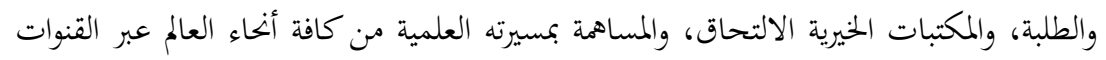

$$
\text { التكنولوجية. }
$$

خامسا: استثمار فائض عائداته العينية والنقدية وفق أنظمة محكمة، مما يعزز ميزانيته العامة، وممايتها من

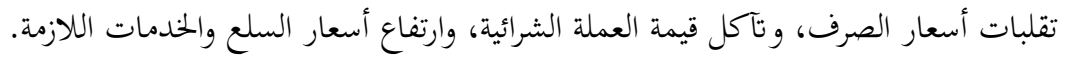

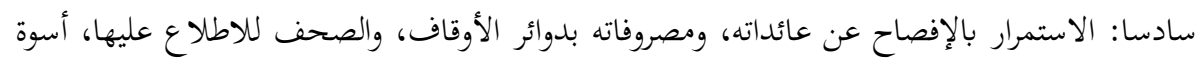

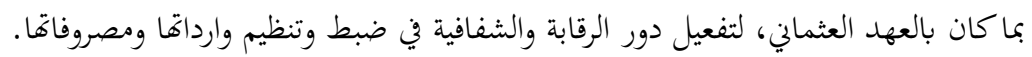




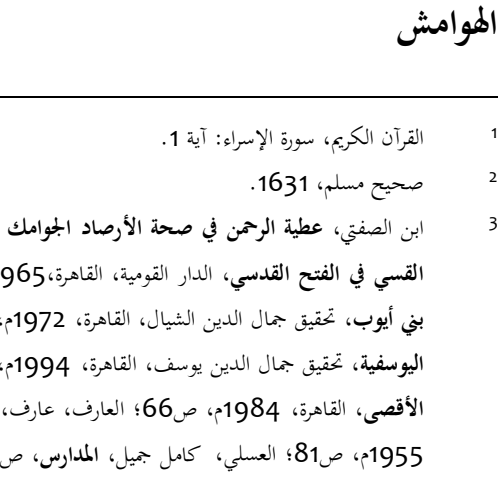

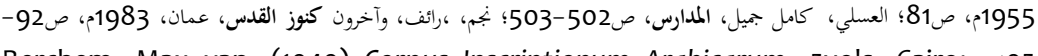
Berchem, Max van. (1949) Corpus Inscriptionum Arabicarum, 5vols. Cairo: ؛ 95 Imprimerie de I'Institute Francais d'Archeologie Orientale, 1922-1949, pp.281-282.

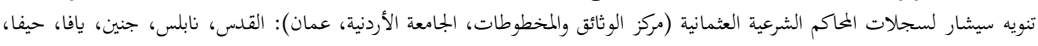

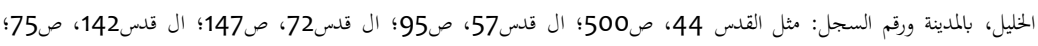

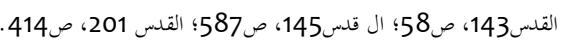

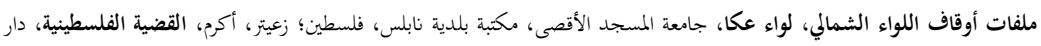

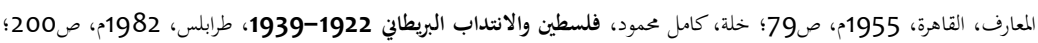

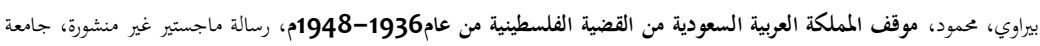

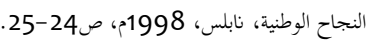

$$
\text { الملحقة: جميع أوقاف المدارس القائمة في داخله وأسواره ألحقت بأوقافه. }
$$

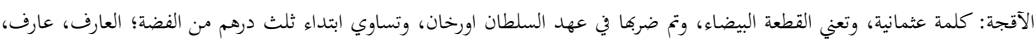

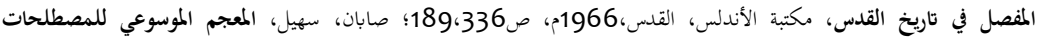

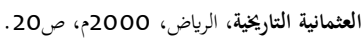

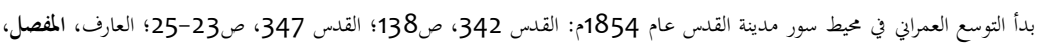
ص303

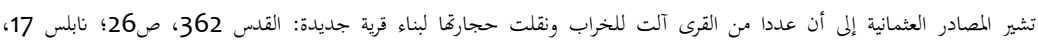

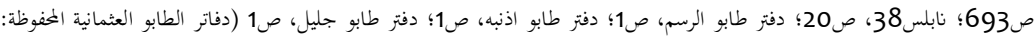
القرش: عملة عثمانية تداولت على نطاق واسع في أسواق الصرف خلال النصف الثاني من القرن التاسع عشر وتساوي (100/1) من الليرة الكيرة

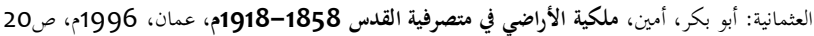

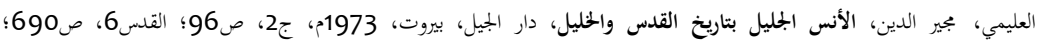

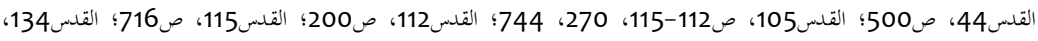

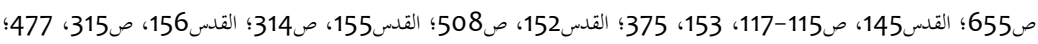

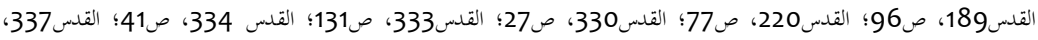

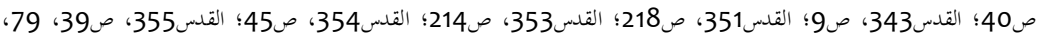

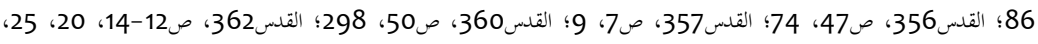

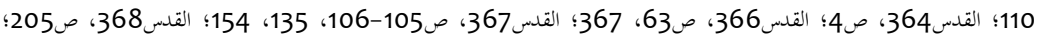

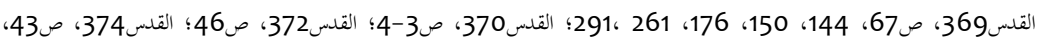

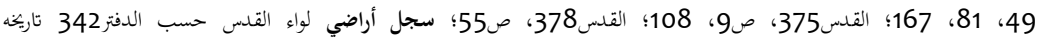

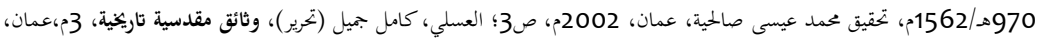

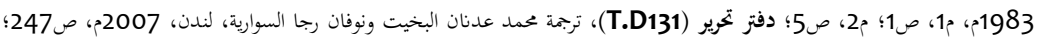


دفتز(T.D427)، ترجمة محمد عدنان البخيت ونوفان رجا السوارية، عمان، 2005م، صادان، 215، 215، 248؛ سجلات الأوقاف

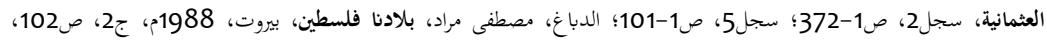

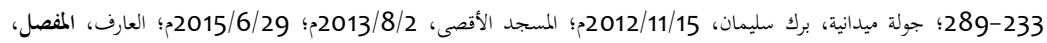

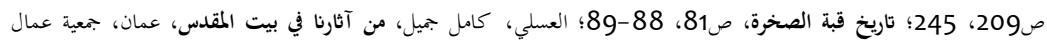

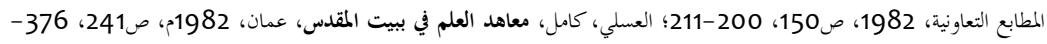

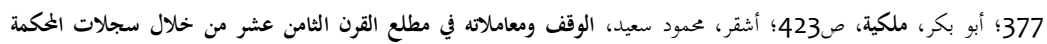

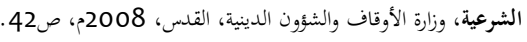

Conder, C.R. and Kitchener, R.E. (1880) Map of Western Palestine, in 26 Sheets from Surveys Conducted for the committee of the Palestine Exploration Fund, during the years 1872-1877. London: The Committee of the Palestine Exploration Fund, p.120121.

Hütteroth, Wolf-Dieter and Abdul-Fattah, Kamal. (1977) Historical Geography of Palestine Transjordan and Southern Syria in the Late sixteen Century. Erlangen: Palm und Enke.

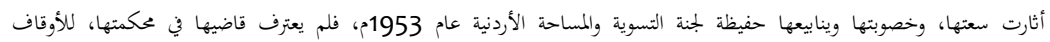

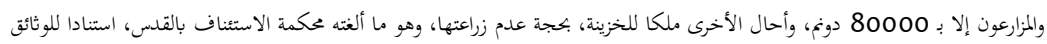

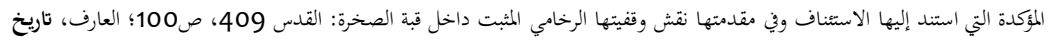

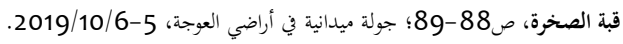

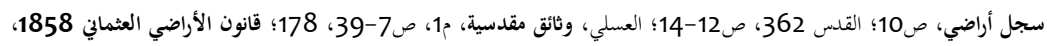

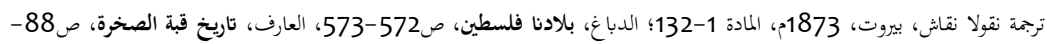

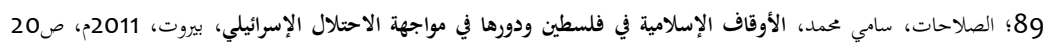

34، 27-26،

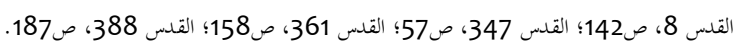

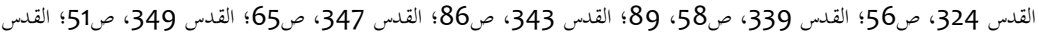

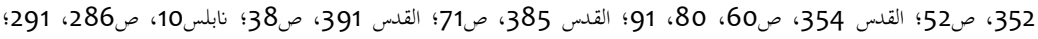

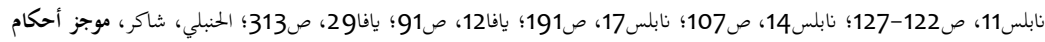

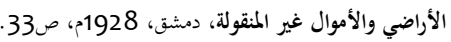

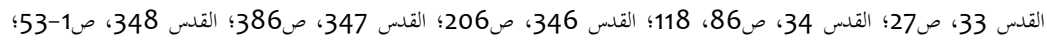

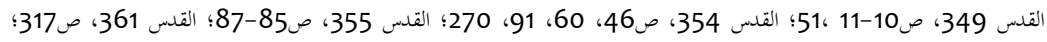

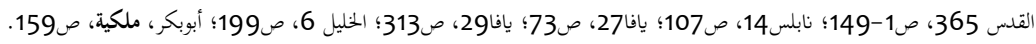

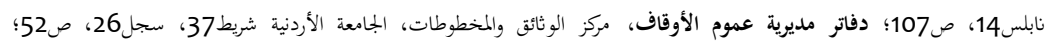

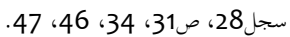
دمبر، مايكل، سياسة إسرائيل تجاه الأوقاف الإسلامية في فلسطين 1947-1988، بيروت، 1992م، ص192؛ أبو بكر، ملكية،

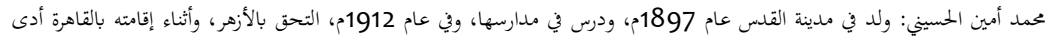

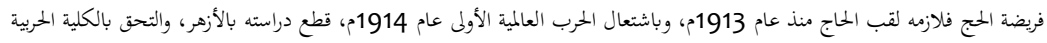

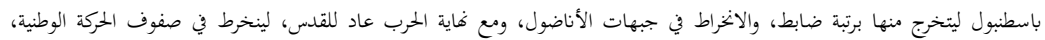

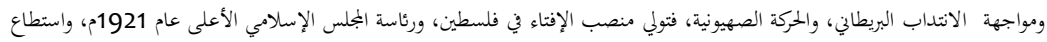

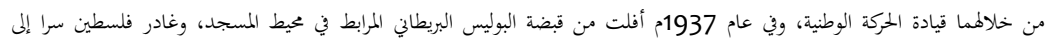


بيروت وظل فيها إلى أن وافته المنية عام 1973م: الحوت، بيان نويهض، القيادات والمؤسسات السياسية في فلسطين، 1917-1948،

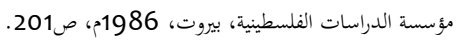
العارف، المفصل، ص244-245؛ جولة ميدانية، المسجد الأقصى، 2019/5/26.

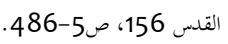

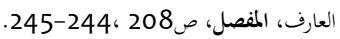

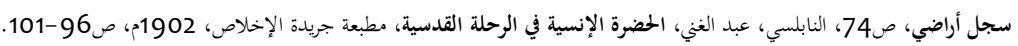

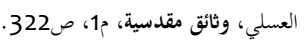
المرجع السابق.

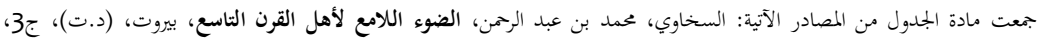

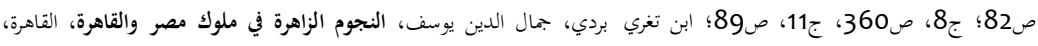

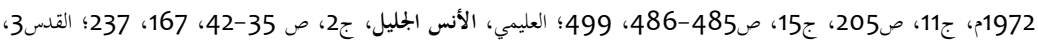

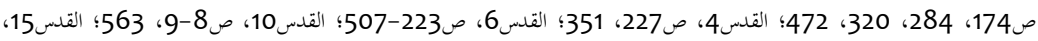

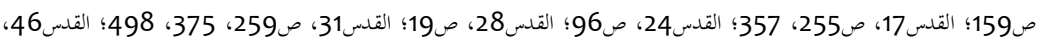

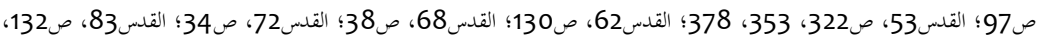

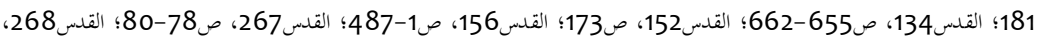

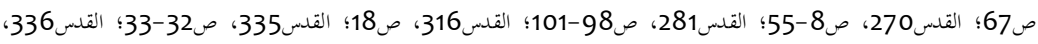

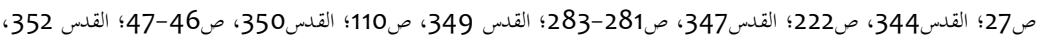

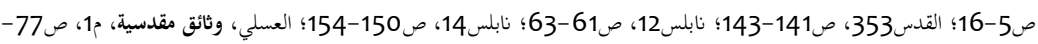

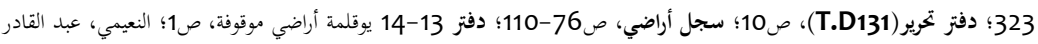

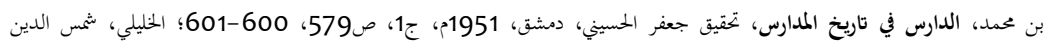

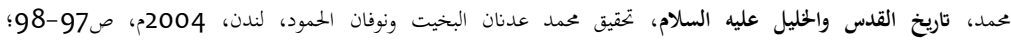
Hütteroth, Historical Geography, pp.138-145; Berchem, Corpus, pp.45-359.

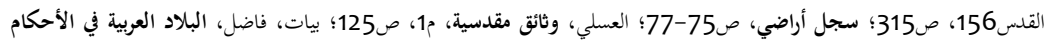

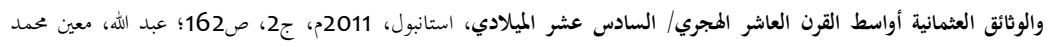
إسماعيل، ملكية الأراضي في قضاء جنين خلال فترة الحكم البريطاني 1918-1948م، رسالة ماجستير غير منشورة، جامعة النجاح العياح

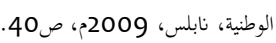

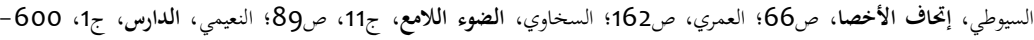

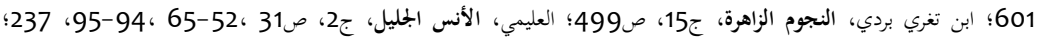

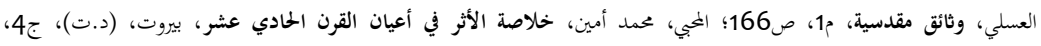

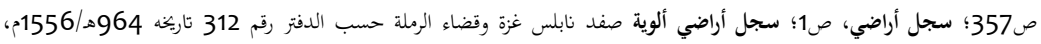

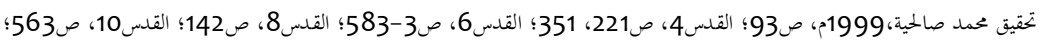

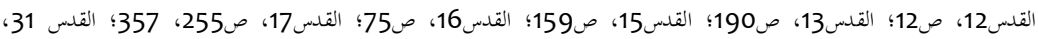

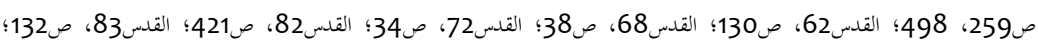

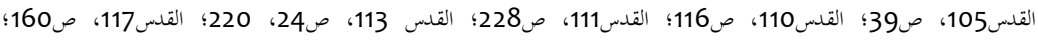

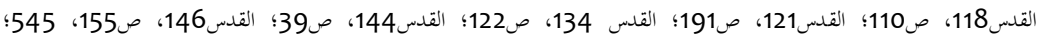

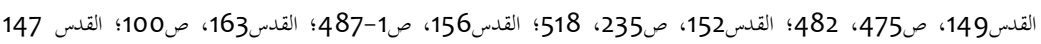

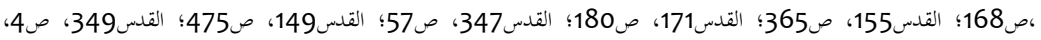

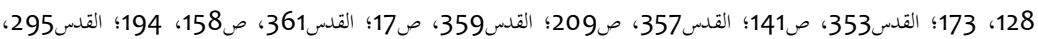




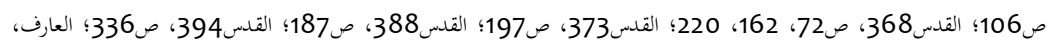

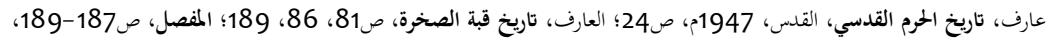

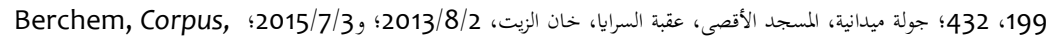

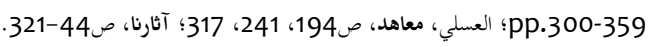
31 3 32 33

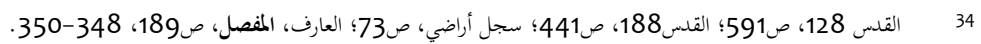

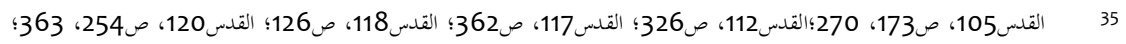

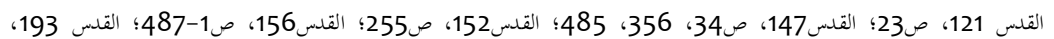

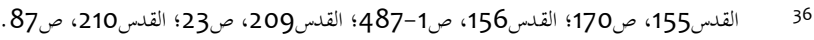

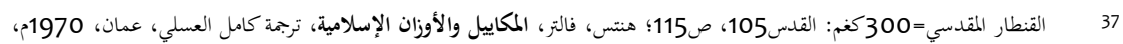
ص

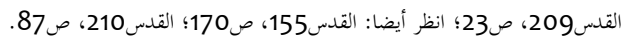

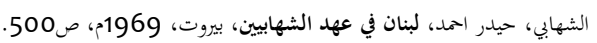
40

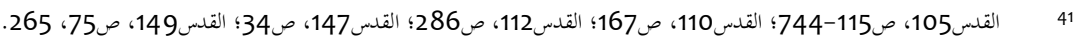

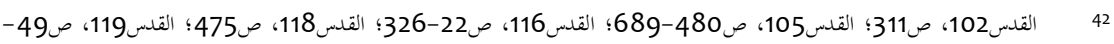

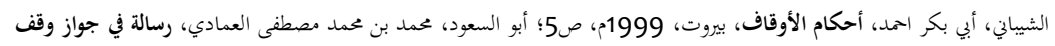

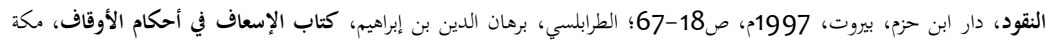

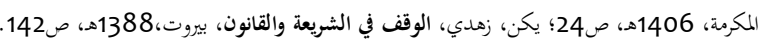

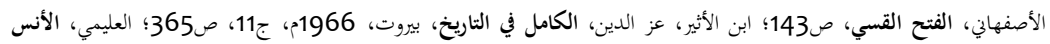

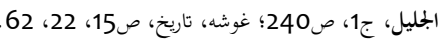

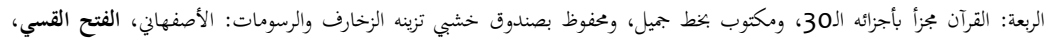

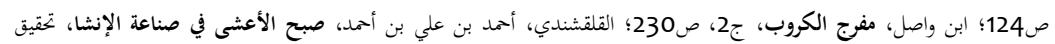

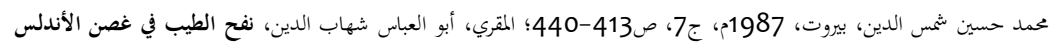

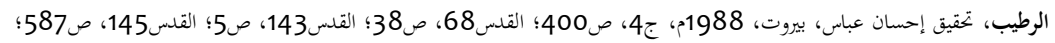

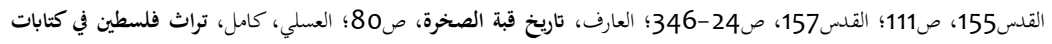

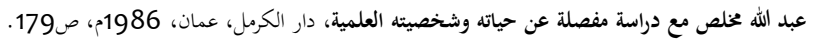

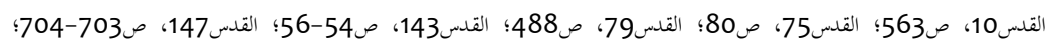

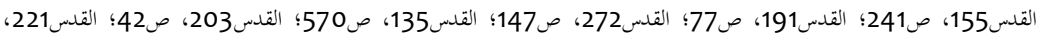
ص333-345؛ القدس403، ص392؛ العمري، احمد بن يميى بن فضل الله، مسالك الأبصار في ممالك الأمصار، تحقيق احمد زكي الفي

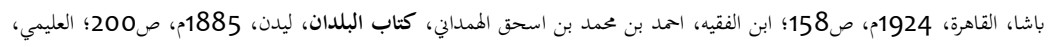

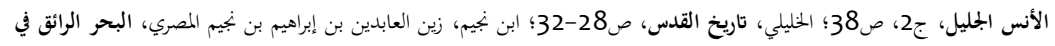

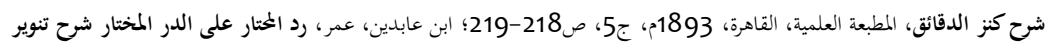

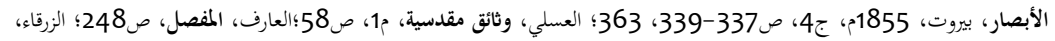

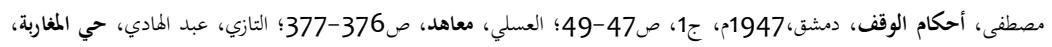

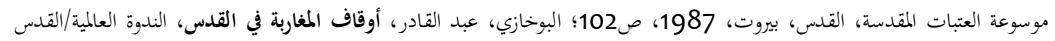


وتراثها الثقافي، الرباط، 1993م، ص333؛ سجل أوقاف، ص13-14، ص18-19؛ يوسف، ج2، ص464، 466، 471؛ غوشه، تاريخ،ص104.

كرد علي، ج6، ص117-119، 195.

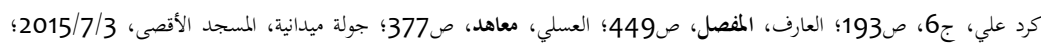
47 .2019/5/26

رسم الكيال:ما يدفعه كيال الحبوب والسوائل من ضرائب للخزينة إزاء كيلها بالمكاييل الرائجة كالصاع، والطبة، والقفة، والفرده، والمد، والكيل

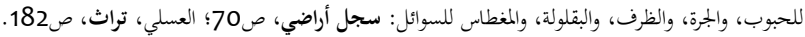

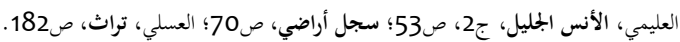

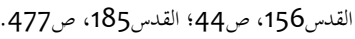

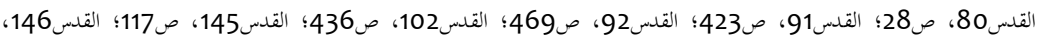

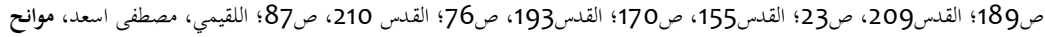

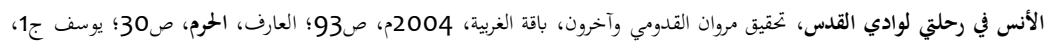

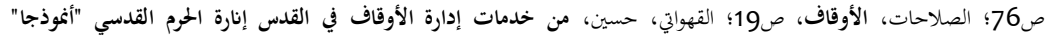

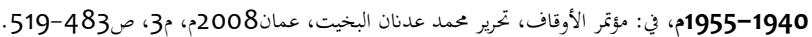

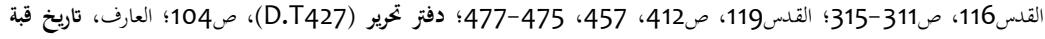

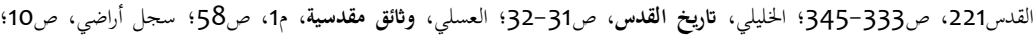

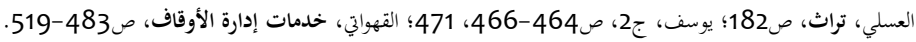
ابن منظور، جمال الدين مكرم، لسان العرب، القاهرة، 2003م، مادة (صرر)؛ البرغوثي، عبد اللطيف، القاموس العربي الشعبي

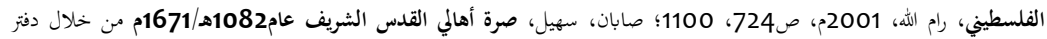

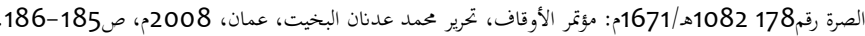

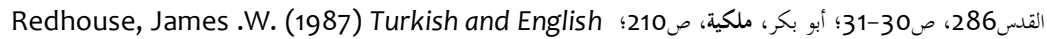
.Lexicon. Beirut: Librairie du Libnan. p.1256 القدس201، ص414؛ العسلي، وثائق مقدسية، م2، ص275-276؛ العارف، المفصل، ص345؛ أوغلي، سويله مز، رحلة سويله مز

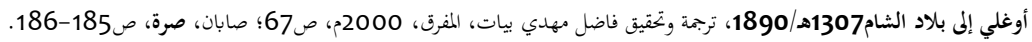

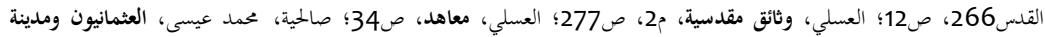

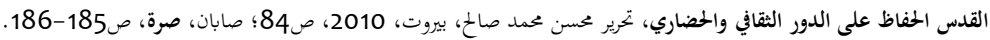

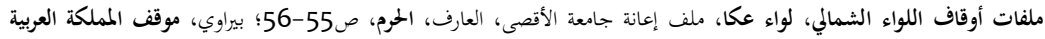
السعودية، ص25-26. 
69 القدس146، ص189؛ القدس156، ص36؛ القدس356، ص18؛ القدس357، ص130؛ القدس370، ص64؛ اوغلي، رحلة

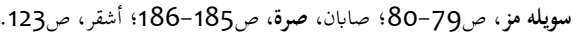

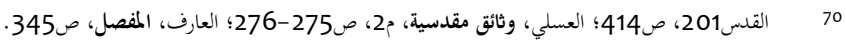

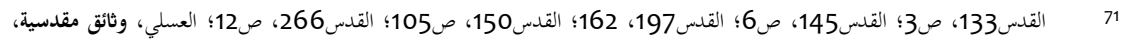
.276-275 ص2 27 العسلي، وثائق مقدسية، م2، ص276، ص276؛ صابان، صرة، ص188-203؛ الحزماوي، محمد ماجد، دفتر الصرة السلطانية(الرومية) لأهالي

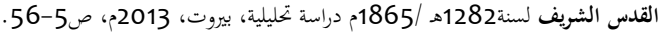

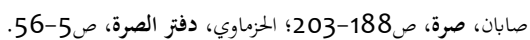

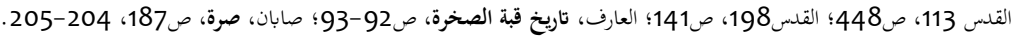
صابان، صرة، ص187.

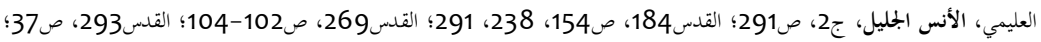

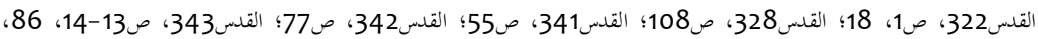

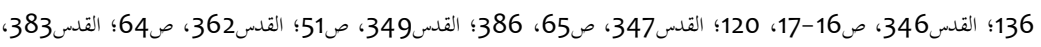

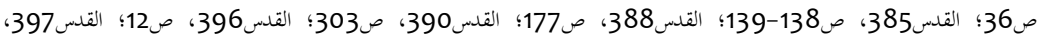

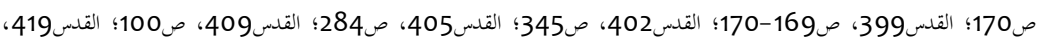

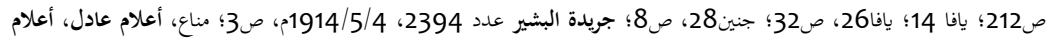

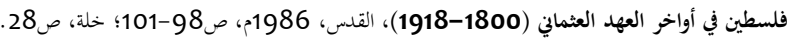

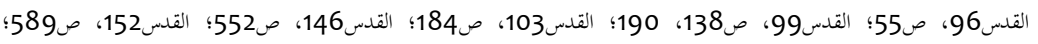

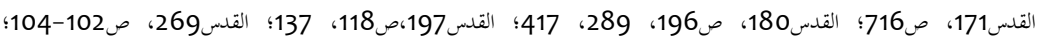

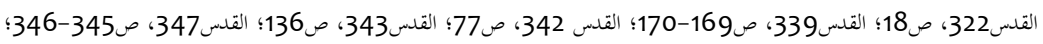

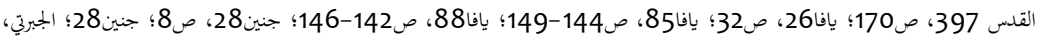

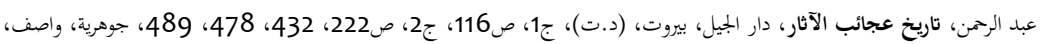

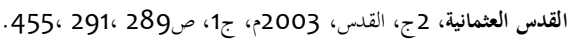

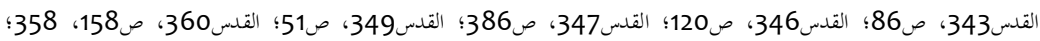

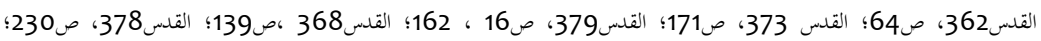

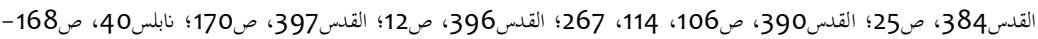

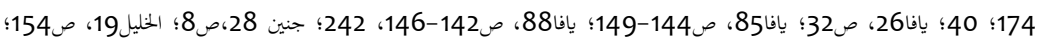

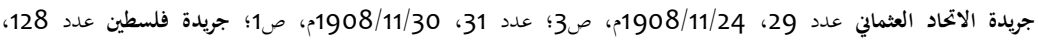

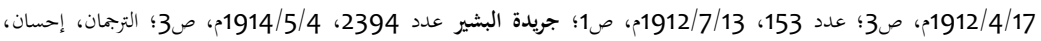

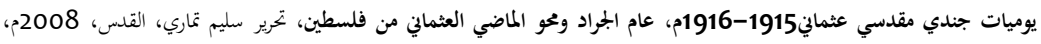

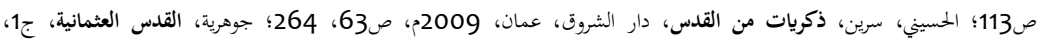
ص2108، ج2، ص289.

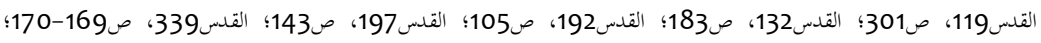

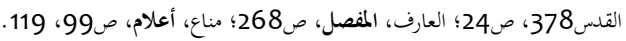

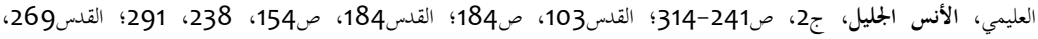

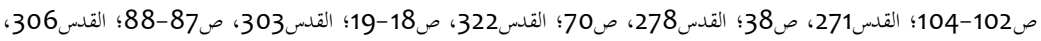

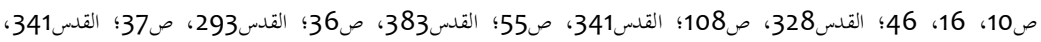

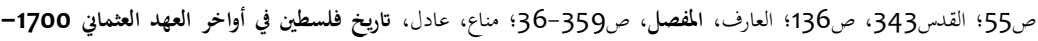
1918 قراءة جديدة، بيروت، 1999م، ص28. 


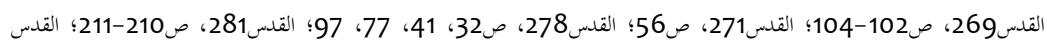
81

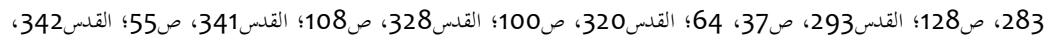

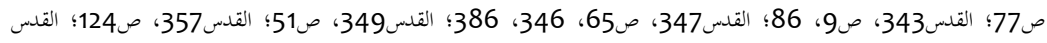

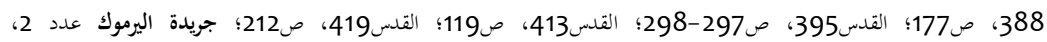

1924/9/11

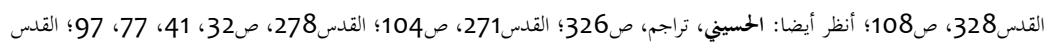

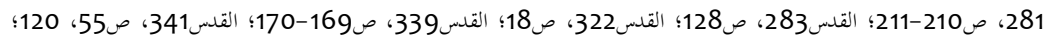

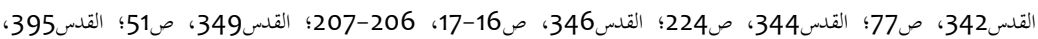

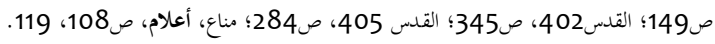

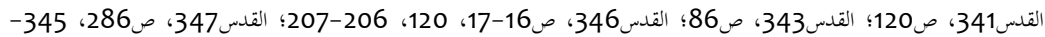

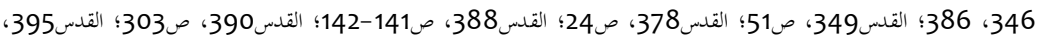

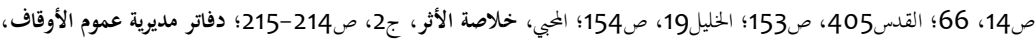

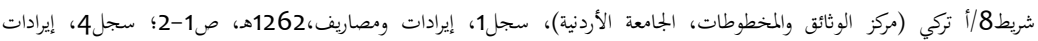

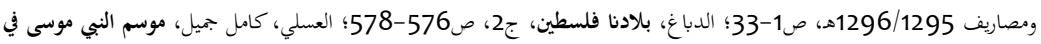

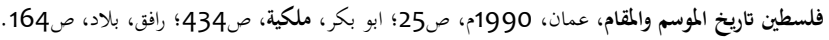

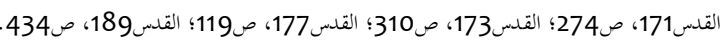
القدس327، ص16؛ القدس329، ص31/16، ص36.

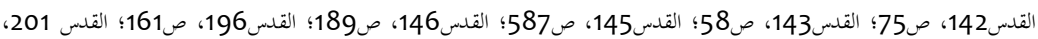

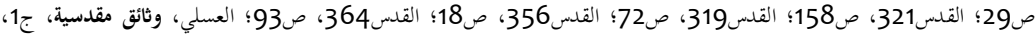

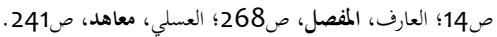

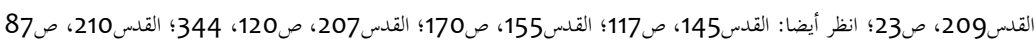

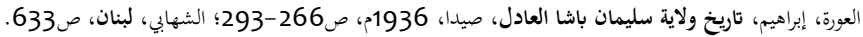

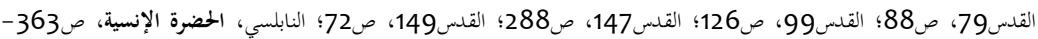

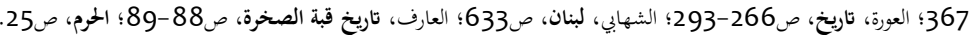

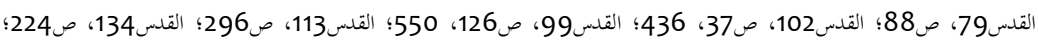

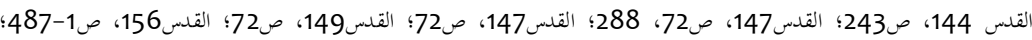

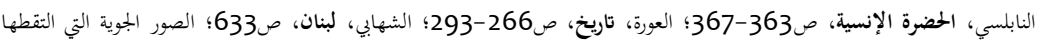

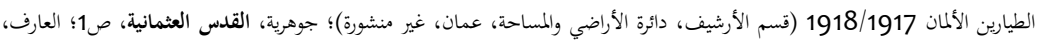
الحرم، ص25-84، 62؛ تاريخ قبة الصخرة، ص10،

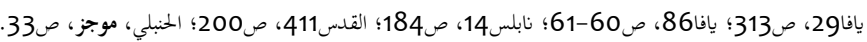

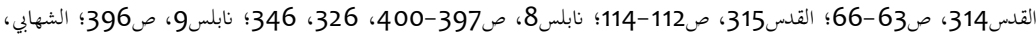

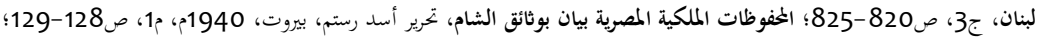
ابو بكر، ملكية، ص288

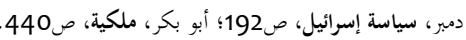

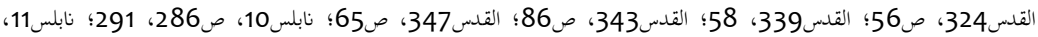

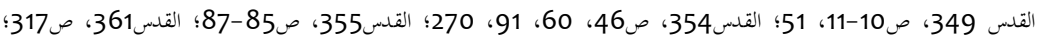

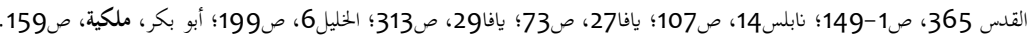


يافا12، ص91؛ يافا29، ص313؛ نابلس14، ص107؛ نابلس11، ص122-127؛ نابلس12، ص122 ص122-127؛ نابلس17، ص 191؛

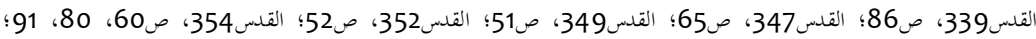

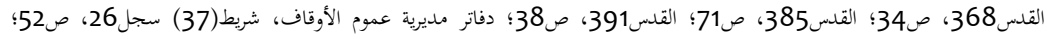

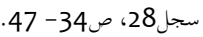

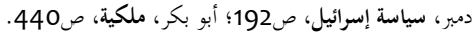

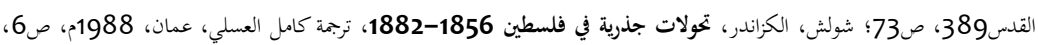

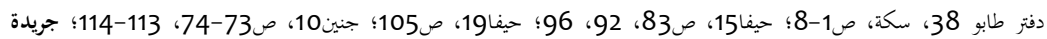

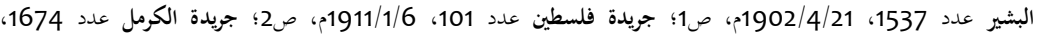

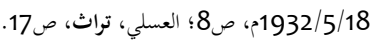

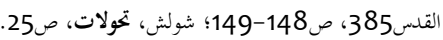
102

103 102 القدس205، ص294-295؛ الخليلي، تاريخ القدس، ص250-250، 151-151، 204-210.

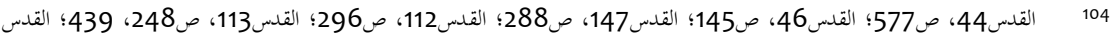

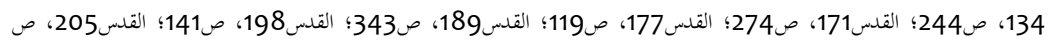

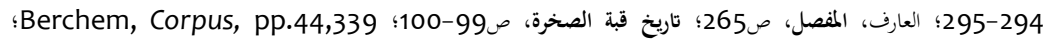
صالحية، العثمانيون، ص2161-215. القدس112، صالحية، العثايون؛ صالقدس113، ص248،

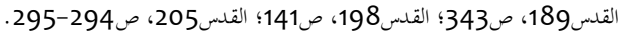

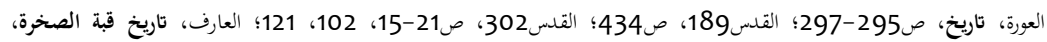

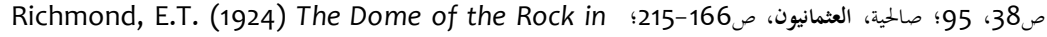
Jerusalem: A Description of Its Structure and Decoration. Oxford: Clarendon. p.19.

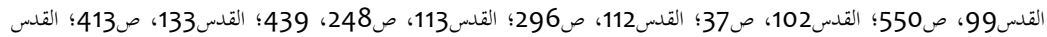

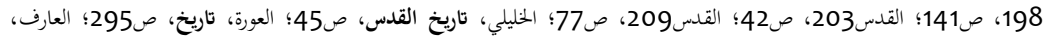

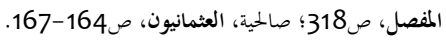

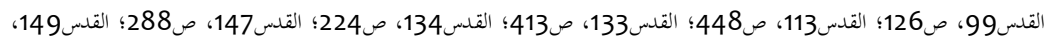

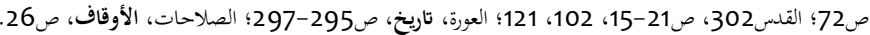

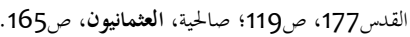

